\title{
Evolution of the chemical fingerprint of biomass burning organic aerosol during aging
}

\author{
Amelie Bertrand ${ }^{1,2, a}$, Giulia Stefenelli ${ }^{3}$, Coty N. Jen ${ }^{4}$, Simone M. Pieber $^{3}$, Emily A. Bruns $^{3}$, Haiyan Ni $^{5}$, \\ Brice Temime-Roussel ${ }^{1}$, Jay G. Slowik ${ }^{3}$, Allen H. Goldstein ${ }^{4}$, Imad El Haddad ${ }^{3}$, Urs Baltensperger ${ }^{3}$, \\ André S. H. Prévôt ${ }^{3}$, Henri Wortham ${ }^{1}$, and Nicolas Marchand ${ }^{1}$ \\ ${ }^{1}$ Aix Marseille Univ, CNRS, LCE, Marseille, France \\ ${ }^{2}$ Agence de l'environnement et de la Maîtrise de l'Energie, 20 avenue du Grésillé - BP 90406, \\ 49004 Angers, CEDEX 01, France \\ ${ }^{3}$ Laboratory of Atmospheric Chemistry, Paul Scherrer Institute, 5232 Villigen, Switzerland \\ ${ }^{4}$ Department of Environmental Sciences, Policy, and Management, University of California at Berkeley, California, USA \\ ${ }^{5}$ Key Lab of Aerosol Chemistry and Physics, State Key Laboratory of Loess and Quaternary Geology, \\ Institute of Earth Environment, Chinese Academy of Sciences, Xi'an, China \\ anow at: Laboratory of Atmospheric Chemistry, Paul Scherrer Institute, 5232 Villigen, Switzerland
}

Correspondence: Nicolas Marchand (nicolas.marchand@univ-amu.fr)

Received: 18 December 2017 - Discussion started: 2 January 2018

Revised: 26 April 2018 - Accepted: 5 May 2018 - Published: 1 June 2018

\begin{abstract}
A thermal desorption aerosol gas chromatograph coupled to a high resolution - time of flight - aerosol mass spectrometer (TAG-AMS) was connected to an atmospheric chamber for the molecular characterization of the evolution of organic aerosol (OA) emitted by woodstove appliances for residential heating. Two log woodstoves (old and modern) and one pellet stove were operated under typical conditions. Emissions were aged during a time equivalent to $5 \mathrm{~h}$ of atmospheric aging. The five to seven samples were collected and analyzed with the TAG-AMS during each experiment. We detected and quantified over 70 compounds, including levoglucosan and nitrocatechols. We calculate the emission factor (EF) of these tracers in the primary emissions and highlight the influence of the combustion efficiency on these emissions. Smoldering combustion contributes to a higher EF and a more complex composition. We also demonstrate the effect of atmospheric aging on the chemical fingerprint. The tracers are sorted into three categories according to the evolution of their concentration: primary compounds, non-conventional primary compounds, and secondary compounds. For each, we provide a quantitative overview of their contribution to the OA mass at different times of the photooxidative process.
\end{abstract}

\section{Introduction}

Organic matter represents a major fraction (20-90\%) of particulate matter (PM; Kanakidou et al., 2005). Organic PM is a complex mixture made up of tens of thousands of compounds (Goldstein and Galbally, 2007), with some of them shown to be carcinogenic (Yu, 2002; Yang et al., 2010). Identifying and quantifying their contribution to the organic PM mass is key in order to resolve its origins and impacts on human health and climate.

Extensive characterization of the molecular composition of primary organic aerosol (POA) emissions has already been conducted. For example, biomass burning emissions from both softwood and hardwood combustions (Simoneit et al., 1993; Fine et al., 2001, 2002, 2004; Nolte et al., 2001; Schauer et al., 2001; Schmidl et al., 2008a), vehicular emissions (Rogge et al., 1993a, b; Fraser et al., 1999; Schauer et al., 2002; El Haddad et al., 2009), and cooking emissions (Hildemann et al., 1991; Nolte et al., 1999; Schauer et al., 1999) have been broadly characterized. The full characterization of these emissions and their contribution to the concentration of total organic aerosol (OA) is of particular interest for source apportionment of ambient PM using molecular markers. In biomass burning emissions, compounds derived from the pyrolysis of cellulose and lignin are 


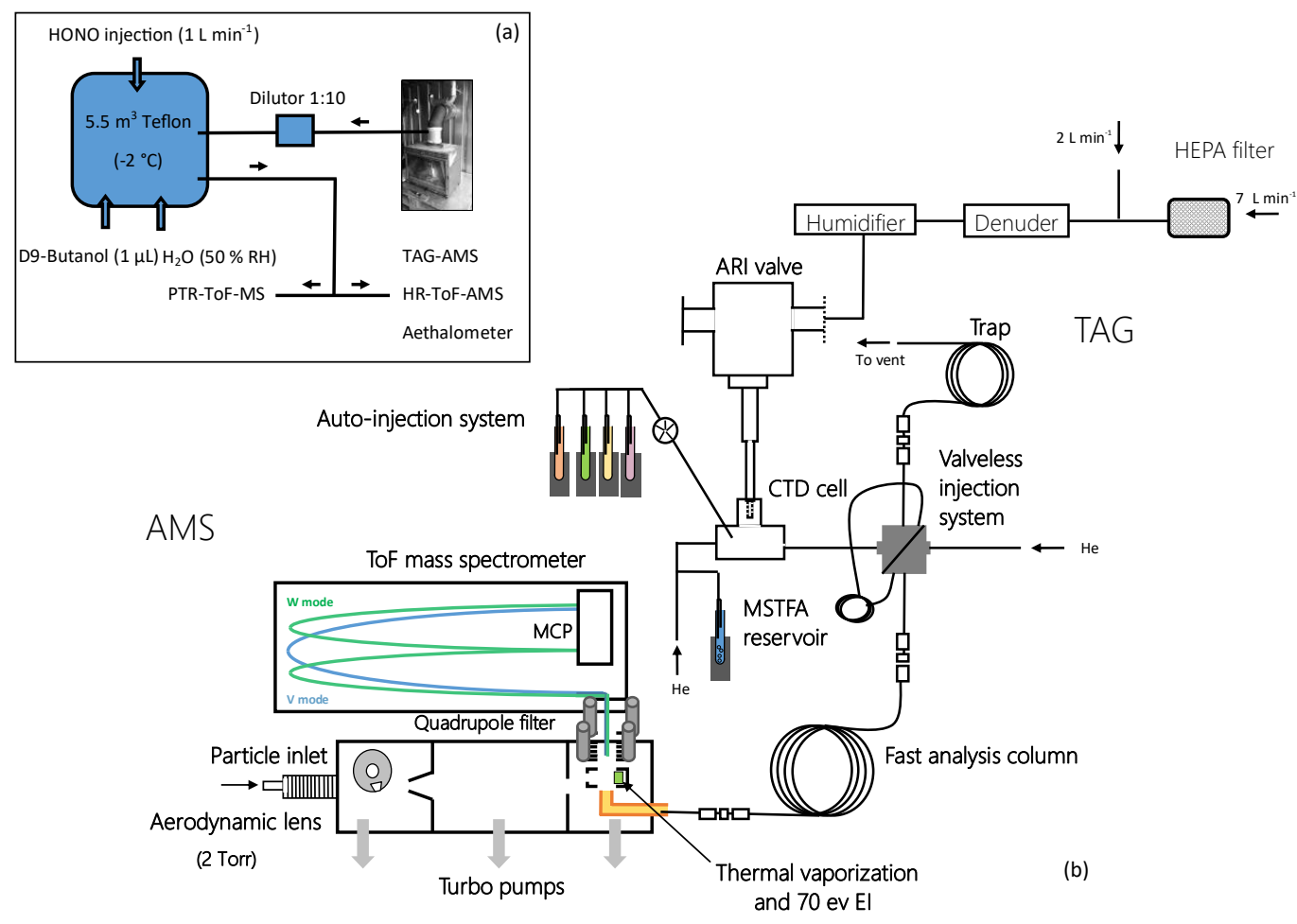

Figure 1. Schemes of the atmospheric chamber setup (a) and TAG-AMS with in situ derivatization (b).

often reported. These include levoglucosan, a sugar anhydride compound and by-product of the thermal degradation of cellulose and a commonly used tracer of biomass burning organic aerosol (BBOA) in source apportionment (Waked et al., 2014; Bonvalot et al., 2016; Maenhaut et al., 2016), as well as methoxyphenols, by-products of the thermal degradation of lignin. In fresh emissions, the emission factors (EFs) of these compounds can vary with the type of fuel (hardwood, softwood, or herbaceous types; Schmidl et al., 2008b; Schauer et al., 2001; Fine et al., 2002, 2004), the type of fire (open fire, fire places, woodstove; Fine et al., 2002, 2004), or even the sampling setup (in an experimental stack, in a dilution tunnel, or ambient; Nussbaumer et al., 2010). Anhydrosugars and methoxyphenols are ubiquitous in the atmosphere impacted by biomass combustions, and have been used to demonstrate the significant contribution of biomass burning to the total organic aerosol source globally (Robinson et al., 2006; Gelencsér et al., 2007; Puxbaum et al., 20 2007; Stone et al., 2010; Crippa et al., 2013).

Meanwhile, data on the evolution of these well-known primary compounds during atmospheric aging of the emissions remain scarce. Authors have typically focused on the gas-phase oxidation of methoxyphenols (Net et al., 2011; Lauraguais et al., 2012, 2014; Yee et al., 2013), only few have specifically addressed the aging of levoglucosan in the particle phase (Hennigan et al., 2010; Kessler et al., 2010; Lai et al., 2014), and only Fortenberry et al. (2018) have attempted to characterize the aged chemical fingerprint of biomass burning emissions at the molecular level, by means of a thermal desorption aerosol gas chromatograph (TAG) connected to a potential aerosol mass (PAM) flow reactor. Such data are of prime importance. Considering that the OA mass concentration from biomass burning can increase up to 7 times during photochemical aging in the atmosphere (Grieshop et al., 2009; Heringa et al., 2011; Ortega et al., 2013; Bruns et al., 2015; Tiitta et al., 2016), the knowledge of the sole primary chemical fingerprint is not sufficient to understand and to assess the global impact of biomass burning on the atmospheric aerosol burden.

In a previous publication, we investigated the POA emissions and secondary organic aerosol (SOA) production potential generated by three woodstove appliances (two log woodstoves and one pellet stove) used for residential heating (Bertrand et al., 2017) using a HR-ToF-AMS. Here, we provide a comprehensive study, including the evolution of the molecular level composition of the emissions during a period equivalent to $5 \mathrm{~h}$ of atmospheric aging. The experiments were conducted using the atmospheric chamber of the Paul Scherrer Institute (PSI, Villigen, Switzerland). The data were obtained by means of a TAG-AMS (Aerodyne Research Inc.). We determine the EF and emission profiles of biomass burning tracers. In a first part, we derive the effect of combustion conditions on the EFs and the contribution of the tracers to the POA mass concentration, and in a second approach we 
determine the effect of the atmospheric aging on the contribution of tracers to the total OA mass.

\section{Materials and methods}

\subsection{Setup}

The full setup and protocol was previously fully described in Bertrand et al. (2017). The atmospheric chamber is a $5.5 \mathrm{~m}^{3}$ Teflon chamber with a set of $40 \times 100 \mathrm{~W}$ UV lights (310$430 \mathrm{~nm}$; Platt et al., 2013) to initiate photo-chemistry (Fig. 1). Whereas most studies conduct their experiments at ambient temperature, here the chamber was set to $2^{\circ} \mathrm{C}$ in order to simulate wintertime conditions. Relative humidity $(\mathrm{RH})$ was kept at $50 \%$. Primary and aged emissions were characterized using a suite of instrumentation. This included a TAG-AMS (Aerodyne Research Inc.) for the online speciation of the OA particle mass (referenced in the text as identified OA), an Aethalometer (Magee Scientific Aethalometer model AE33; Drinovec et al., 2015) for the quantification of the equivalent black carbon (eBC) concentration, a HR-ToF-AMS (Aerodyne Research Inc.) for the bulk-condensed chemical composition and quantification of the non-refractory fraction of the aerosol (total OA, sulfate, nitrate, ammonium), and a proton transfer reaction - time of flight - mass spectrometer (PTR-ToF-MS 8000, Ionicon Analytik) for the monitoring of volatile organic compounds (VOCs). The PTR-ToF-MS was operated under standard conditions, i.e., ion drift pressure at $2.2 \mathrm{mbar}$ and drift field intensity at $125 \mathrm{Td}$ (Townsend unit, $1 \mathrm{Td}=10^{-21} \mathrm{~V} \mathrm{~m}^{2}$ ). The HR-ToF-AMS was equipped with a $\mathrm{PM}_{2.5}$ aerodynamic lens and operated under standard conditions, i.e., the temperature of the vaporizer was set to $600{ }^{\circ} \mathrm{C}$ and the electron ionization (EI) to $70 \mathrm{eV}$.

Emissions were generated by three different wood burning appliances. Stove A was a log woodstove fabricated before 2002, stove B a log woodstove fabricated in 2010, and stove $\mathrm{C}$ a pellet stove from 2010 . For each stove, experiments were replicated 3 or 4 times (Table 1). The log woodstoves were loaded with $2-3 \mathrm{~kg}$ of beech wood as logs and kindling wood, and with a moisture content between 10 and $12 \%$. The pellet stove was fueled with commercial pellets, considered premium quality (European Standards, 2012), composed of a mixture of pine and spruce wood, and with a moisture content of $7.7 \%$ and a density of $600 \mathrm{~kg} \mathrm{~m}^{-3}$. The stoves were connected from the chimney to the chamber via heated $\left(140^{\circ} \mathrm{C}\right)$ Silico-steel lines.

\subsection{Experimental protocol}

Following ignition and prior to injection into the chamber, the emissions were diluted by a factor of 10 through an ejector dilutor (DI-1000, Dekati Ltd.). After injection and prior to aging, the mass concentration of $\mathrm{OA}$ in the chamber ranged between 10 and $177 \mu \mathrm{g} \mathrm{m}^{-3}$ (Table 1) and can thus be considered representative of ambient to plume- like conditions. The concentration of $\mathrm{NO}_{x}$ ranged from 50 to $255 \mathrm{ppb}$. Primary emissions were left static for approximately $30 \mathrm{~min}$ for homogenization and stabilization. Then, $1 \mu \mathrm{L}$ of butanol-D9 (butanol-D9, $98 \%$, Cambridge Isotope Laboratories) was injected. Butanol-D9 is a commonly used tracer for hydroxyl radicals $(\mathrm{OH})$ in atmospheric chamber studies (Platt et al., 2013; Bruns et al., 2015; Klein et al., 2016). Its main fragment is at $m / z 66.126\left(\left[\mathrm{C}_{4} \mathrm{D}_{9}\right]^{+}\right)$, which can be easily monitored by means of a PTR-ToF-MS (Barmet et al., 2012). Nitrous acid (HONO) was injected continuously at a flow rate of $1 \mathrm{~L} \mathrm{~min}^{-1}$. HONO dissociates under UV light $(\lambda<400 \mathrm{~nm})$ to form $\mathrm{OH}$. Here, to integrate the dilution factor owing to the continuous injection of HONO into the chamber, we retrieved the $\mathrm{OH}$ exposure $(\mathrm{OH}$ concentration integrated over time) based on the differential reactivity of butanol-D9 and naphthalene $\left(\left[\mathrm{C}_{10} \mathrm{H}_{8}\right] \mathrm{H}^{+}, m / z\right.$ 129.070). The photo-oxidation of the emissions lasted for approximately $4 \mathrm{~h}$. We calculated an integrated $\mathrm{OH}$ exposure at the end of our experiments that ranged between $5 \times 10^{6}$ and $8 \times 10^{6}$ molecules $\mathrm{cm}^{-3} \mathrm{~h}$. This translates to 5 to $8 \mathrm{~h}$ of atmospheric aging, respectively, with a typical average daytime $\mathrm{OH}$ concentration of $1 \times 10^{6} \mathrm{OH}$ molecules $\mathrm{cm}^{-3}$.

\subsection{Operation of the TAG-AMS}

The TAG-AMS (Fig. 1) permits the online collection and analysis of the OA particles at the molecular level with a time resolution of $<1$ hour. The instrument presented here is a modified version of the original TAG system (Williams et al., 2006). The TAG is coupled to a modified HR-ToF-AMS (DeCarlo et al., 2006) equipped with a quadrupole high-pass filter (Tofwerk) and opened at the rear flange to accommodate a transfer line (Williams et al., 2014). The quadrupole deflects any ions at $m / z<10$. This avoids the saturation of the detector by helium, used as the carrier gas in the TAG system. The transfer line connects the gas chromatography (GC) column of the TAG to the bottom of the ion cage inside the AMS. It consists of a coated stainless steel capillary, 15 inches long and 1/32-inch outer diameter, which is contained within a heated copper rod. The transfer line is maintained at all times at $300^{\circ} \mathrm{C}$. This TAG-AMS was also implemented with an online derivatization system for the analysis of more polar compounds (Isaacman et al., 2014).

Emissions are sampled and passed through a parallel plate charcoal denuder to remove trace gases. The aerosol is then humidified (65-95\% RH) to enhance the collection efficiency onto the collection thermal desorption (CTD) cell. The CTD cell is kept at ambient temperature during sampling and then heated progressively (in $4 \mathrm{~min}$ ) to $280^{\circ} \mathrm{C}$ for the measurement. Analytes are thermally desorbed into a helium flow enriched with the derivatization agent $\mathrm{N}$ methyl-N-trimethylsilyl trifluoroacetamide (MSTFA, Sigma Aldrich). This derivatization flow is then routed to the cell in parallel with a pure helium flow (purge flow). The derivatization and purge flows were set to 40 and $15 \mathrm{~cm}^{3} \mathrm{~min}^{-1}$, 
Table 1. Summary of the experiments and conditions in the chamber before lights-on (after a homogenization and stabilization period). MCE stands for modified combustion efficiency and THC is total hydrocarbon.

\begin{tabular}{|c|c|c|c|c|c|c|c|c|c|}
\hline Stove & Exp no. & MCE & $\begin{array}{r}\text { No. of } \\
\text { TAG-AMS } \\
\text { samples }\end{array}$ & $\begin{array}{r}{ }^{*}[\mathrm{eBC}] \\
\left(\mu \mathrm{g} \mathrm{m}^{-3}\right)\end{array}$ & $\begin{array}{r}{ }^{*}[\mathrm{POA}] \\
\left(\mu \mathrm{g} \mathrm{m}^{-3}\right)\end{array}$ & $\begin{array}{r}{ }^{* *}[\mathrm{OA}] \\
\left(\mu \mathrm{g} \mathrm{m}^{-3}\right)\end{array}$ & $\begin{array}{r}*\left[\mathrm{NO}_{x}\right] \\
(\mathrm{ppb})\end{array}$ & $\begin{array}{r}{[\mathrm{THC}] /\left[\mathrm{NO}_{x}\right]} \\
\quad\left(\mathrm{ppb} \mathrm{ppb}^{-1}\right)\end{array}$ & $\begin{array}{r}{[\text { Cresol }] /\left[\mathrm{NO}_{x}\right]} \\
\quad\left(\mathrm{ppb} \mathrm{ppb}^{-1}\right)\end{array}$ \\
\hline \multirow{4}{*}{$\begin{array}{l}\text { Stove A } \\
(\text { Beech as logs) }\end{array}$} & Exp 1 & 0.85 & 6 & 17 & 122 & 495 & 98 & 31.5 & $1.1 \times 10^{-1}$ \\
\hline & Exp 2 & 0.84 & 7 & 12 & 177 & 785 & 252 & 26.9 & $1.1 \times 10^{-1}$ \\
\hline & Exp 3 & 0.83 & 7 & 6 & 71 & 388 & 90 & 38.5 & $1.2 \times 10^{-1}$ \\
\hline & Exp 4 & 0.91 & 8 & 5 & 10 & 72 & 128 & 7.7 & $2.7 \times 10^{-2}$ \\
\hline \multirow{4}{*}{$\begin{array}{l}\text { Stove B } \\
\text { (Beech as logs) }\end{array}$} & Exp 5 & 0.80 & 7 & 5 & 41 & 143 & 50 & 47.2 & $1.2 \times 10^{-1}$ \\
\hline & Exp 6 & 0.87 & 7 & 13 & 38 & 202 & 119 & 18.1 & $5.0 \times 10^{-2}$ \\
\hline & Exp 7 & 0.82 & 6 & 6 & 45 & 289 & 114 & 24.3 & $7.2 \times 10^{-2}$ \\
\hline & Exp 8 & 0.90 & 7 & 4 & 9 & 53 & 80 & 19.6 & $4.5 \times 10^{-2}$ \\
\hline \multirow{3}{*}{$\begin{array}{l}\text { Stove C } \\
\text { (Softwood } \\
\text { pellets) }\end{array}$} & Exp 9 & 0.97 & 5 & 107 & 10 & 19 & 161 & 5.2 & $1.2 \times 10^{-3}$ \\
\hline & Exp 10 & 0.97 & 6 & 130 & 10 & 19 & 205 & 5.8 & $4.7 \times 10^{-4}$ \\
\hline & Exp 11 & 0.97 & 5 & 144 & 10 & 22 & 228 & 5.9 & $3.5 \times 10^{-4}$ \\
\hline
\end{tabular}

* Values retrieved just before lights on

** Values retrieved at integrated $\mathrm{OH}$ exposure $=5 \times 10^{6}$ molecules $\mathrm{cm}^{-3} \mathrm{~h}$.

respectively, so as to ensure complete derivatization of the more polar compounds. The organic material is transferred onto a focusing trap $(15 \mathrm{~m} \times 0.53 \mathrm{~mm}$ inner diameter $\times 5 \mu \mathrm{m}$ film thickness (df) MXT-1 Restek column). During the transfer, the column is kept at $40^{\circ} \mathrm{C}$. Excess MSTFA is flushed out of the system in a subsequent purging step for approximately 4 min. In addition, compounds with a higher volatility than MSTFA are also flushed out. However, this does not affect the analytes of interest studied here. The separation of the analytes is achieved using a $15 \mathrm{~m}$ long $\times 0.18 \mathrm{~mm}$ diameter ValcoBond-5 fast GC capillary column. The initial temperature of the column is $45^{\circ} \mathrm{C}$ and is then increased by $36^{\circ} \mathrm{C} \mathrm{min}^{-1}$ to $100^{\circ} \mathrm{C}$, then by $30^{\circ} \mathrm{C} \mathrm{min}^{-1}$ to $310^{\circ} \mathrm{C}$, and held for 5 min. We show chromatograms in Fig. S1 of the Supplement. Peak fitting and integration are achieved using the TERN (version 1.0; Isaacman-VanWertz et al., 2017) data analysis toolkit in Igor Pro 6.3 (Wave Metrics).

For optimum results, the TAG-AMS should sample air at $9 \mathrm{~L} \mathrm{~min}^{-1}$. In order to make full use of the TAG-AMS without rapidly depleting the volume of the chamber, the sampling flow rate was restricted to $2 \mathrm{~L} \mathrm{~min}^{-1}$. An additional line that sampled outside air filtered through a high-efficiency particulate air (HEPA) filter was installed to make up for the missing flow rate.

Five to seven samples were collected in each experiment. The first sample was systematically collected before photooxidation of the emissions (POA or fresh sample). Sampling lasted between 5 and $25 \mathrm{~min}$, depending on the OA concentration measured in the chamber by the HR-ToF-AMS. To compensate for the loss of materials to the walls (see Sect. 2.4) during aging, the TAG-AMS sampling time was typically increased with each new sampling (Fig. 2).

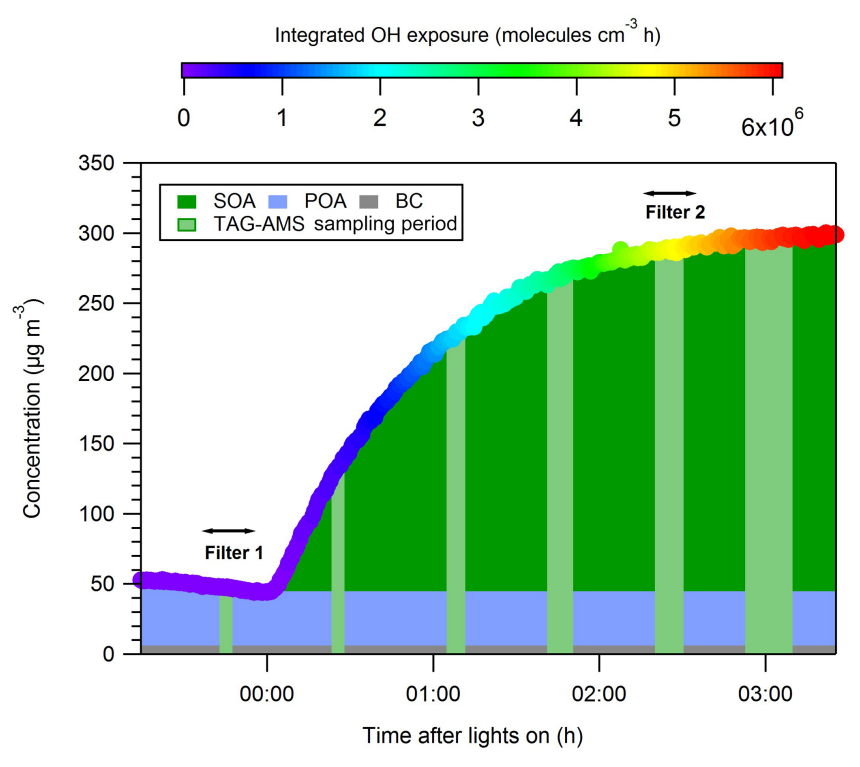

Figure 2. Example of the TAG-AMS and offline (quartz fiber filters) measurements sampling schedule during an aging experiment conducted at the PSI atmospheric chamber with emissions generated from woodstove appliances (Exp. 7, stove B). One sampling with the TAG-AMS is carried out before lights on to characterize POA. At $t=0 \mathrm{~h}, \mathrm{HONO}$ is injected and the lights turned on to initiate photo-chemistry. The four to six samples were taken during the aging period.

Identification of the compounds for which the authentic standards were available (Table S1 in the Supplement) was performed based on their retention times and EI mass spectra. Identification of the compounds for which the authentic standards were not available was performed by match- 
Log woodstove A
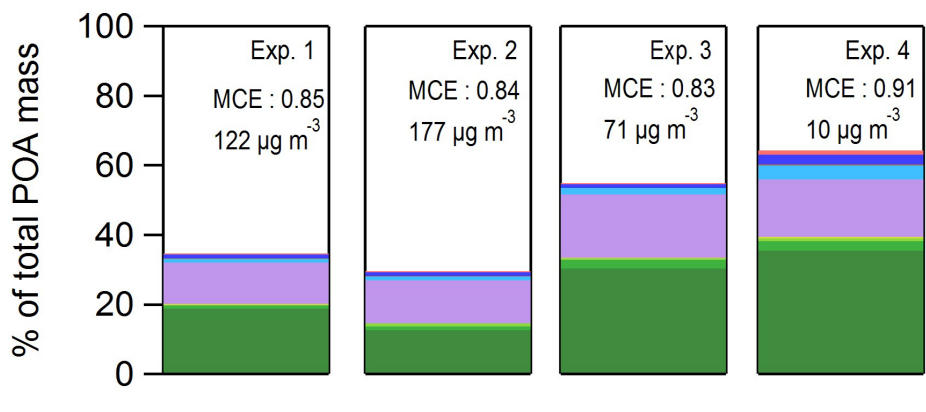

Log woodstove B
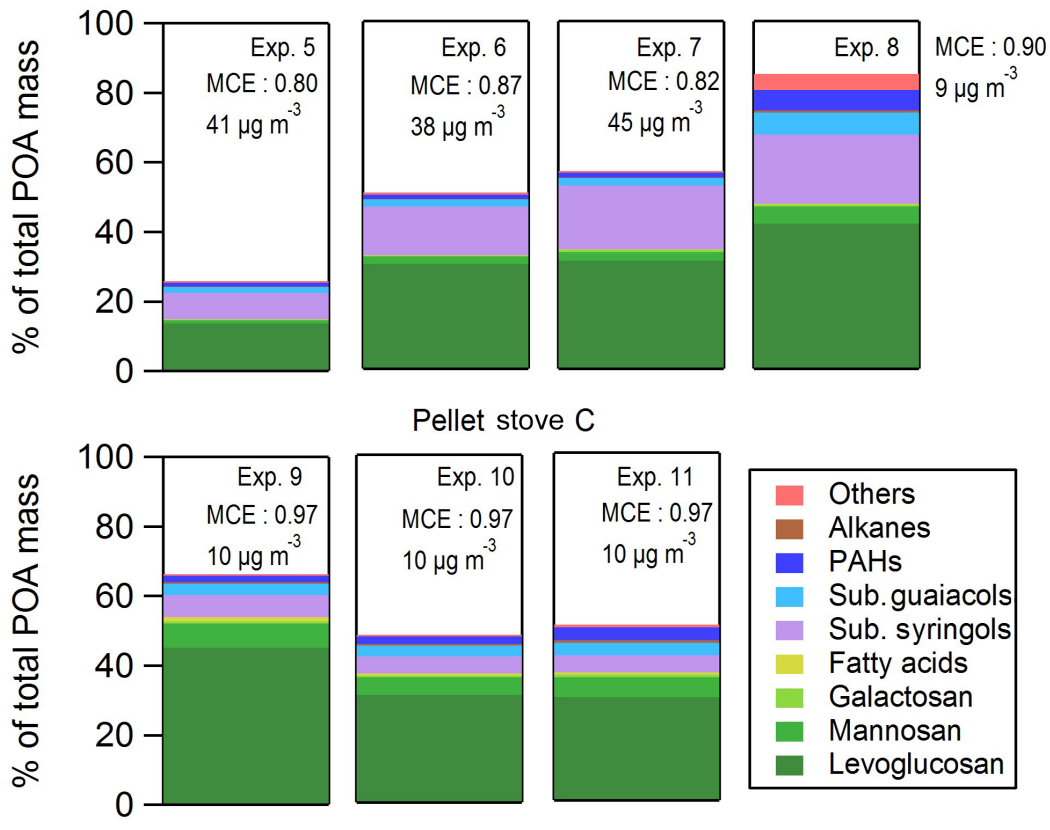

Figure 3. Contribution of the organic markers measured by the TAG-AMS to the total POA mass concentration (indicated on graph) measured by the HR-ToF-AMS for all experiments.

ing their EI mass spectrum to the Wiley and National Institute of Standards and Technology (NIST) mass spectral libraries. The identification of the compounds was also supported by 2D-GC analysis in both EI and vacuum ultra violet (VUV) ionization carried out on one pair of offline samples (quartz fiber filters) collected before and at the end of the aging phase, as illustrated in Fig. 2. Details of the 2D-GC analytical procedure are provided in the Supplement (Fig. S2). For quantification, a deuterated internal standard mixture in acetonitrile was added prior to analysis of each sample in the CTD cell via an automatic injection system developed by Isaacman et al. (2011). The standard mixture included adipic acid-D10, phthalic acid-D4, eicosane-D42, and tetracosaneD50 (Sigma Aldrich). A 5-point mass calibration curve of the authentic standards was achieved before and after the campaign. One point was rerun all along the campaign to check the calibration. The response varied by $<10 \%$. Compounds for which the authentic standard was not available were quantified using an appropriate surrogate (Table S1). Detection limits are presented in Table S2.

\subsection{Particle wall loss corrections (pWLC) and emission factor (EF) calculations}

The mass concentrations were corrected for particle wall loss following the method described in Weitkamp et al. (2007) and Hildebrandt et al. (2009). Briefly, the first order decay of an inert tracer, here $\mathrm{eBC}$, was used to estimate the fraction of condensed material lost to the wall. The corrected mass concentration for particle wall losses, $C_{\mathrm{pWLC}}$, of a species was calculated following Eq. (1):

$C_{\mathrm{pWLC}}(t)=C_{p}(t)+\int_{0}^{t} k_{\mathrm{wall} / \mathrm{p}}(t) C_{p}(t) \mathrm{d} t$,

where $C_{p}$ is the concentration of a species measured by the TAG-AMS or HR-ToF-AMS, $t$ is the time since lights 

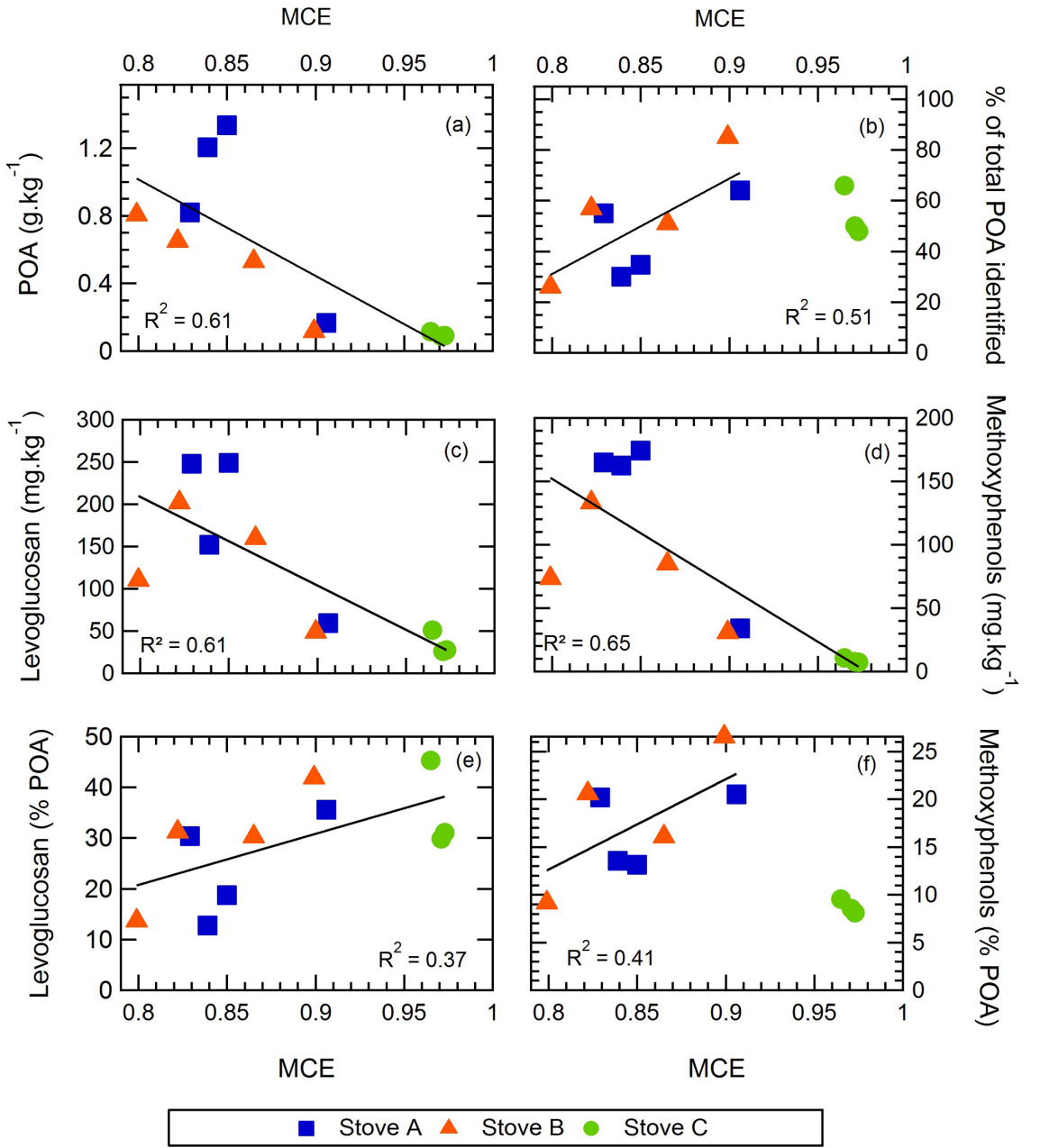

Figure 4. Emissions factors of POA, levoglucosan, and methoxyphenols, as well as their contribution to the total OA as a function of the modified combustion efficiency (MCE). Details on how the MCE was calculated are given in Bertrand et al. (2017).

on (in $\min$ ) and $k_{\mathrm{wall} / p}$ is the eBC wall loss rate constant (0.003-0.006 $\left.\mathrm{min}^{-1}\right)$. Unless stated otherwise, all concentrations and contributions of a marker to OA reported below are corrected for particle wall loss.

This method assumes that the condensable material partitions only to the suspended particles and vapor wall losses are considered negligible. The corrected OA mass concentration and that of the individual markers thus correspond to the lowest estimate possible of the total mass formed. Unlike particle wall loss, vapor wall loss cannot be easily constrained by external measurements. To estimate the loss rate, one would need to conduct a thorough investigation of several key parameters (e.g., each compound's saturation vapor concentration, particle mass accommodation coefficient, or equivalent organic mass concentration at the wall), which are not yet properly constrained within the existing literature. Investigation into vapor wall loss is beyond the scope of this paper but is addressed in Bertrand et al. (2018). Concentrations reported here are not corrected for vapor wall loss.
EFs were calculated based on the method by Andreae and Merlet (2001; Eq. 2). The equation relates the mass emitted of a pollutant $P$ to that of the amount of fuel burnt.

$\mathrm{EF}_{p}=\frac{\Delta P}{\Delta C_{\mathrm{CO}_{2}}+\Delta C_{\mathrm{CO}}+\Delta C_{\mathrm{THC}}+\Delta C_{\mathrm{OC}}+\Delta C_{\mathrm{eBC}}} \cdot W_{\mathrm{c}}$

Here $\Delta$ refers to the change in concentration of the species in the atmospheric chamber between background and emission or stabilization. $C$ relates to the carbon masses of $\mathrm{CO}_{2}, \mathrm{CO}$, THC (total hydrocarbon including methane), organic carbon $(\mathrm{OC})$, and equivalent black carbon (eBC). OC was inferred from the organic matter to $\mathrm{OC}$ ratio $(\mathrm{OM} / \mathrm{OC})$ determined with the high-resolution AMS analysis (Canagaratna et al., 2015). The carbon content $\left(W_{\mathrm{c}}\right)$ of the beech logs and the pellets were determined in the laboratory by analyzing sawdust of the wood samples with an elemental analyzer (Flash HT, Thermo Fisher) and was $46 \pm 1 \%(n=8, w / w)$ for both types of wood (Bertrand et al., 2017). 


\section{Results}

We identified and quantified 71 compounds. They include the anhydrosugars (levoglucosan, mannosan, and galactosan), the methoxyphenols (substituted guaiacols and substituted syringols, details in Sect. 3.2.2), a variety of polycyclic aromatic hydrocarbons (PAHs, including methylated PAHs and oxygenated PAHs), alkanes $\left(\mathrm{C}_{18}\right.$ to $\left.\mathrm{C}_{27}\right)$, fatty acids (saturated and unsaturated), and a variety of tracers found almost exclusively in the aged emissions (see Sect. 3.2.3). Together, these compounds contribute between 26 and $85 \%$ of the total POA mass concentration measured by HR-ToF-AMS (Fig. 3). Their EFs for the primary emissions are reported in Table S3 of the Supplement.

\subsection{Effect of burning conditions on the POA chemical composition}

There exists a strong variability between the experiments regarding the contribution of the markers to the total POA mass concentration as well as their EF (Fig. 4). The influence of fuels on the EF of organic markers has already been extensively reported in the literature (Simoneit et al., 1993; Fine et al., 2001, 2002). Therefore, in the next sections, we focus on the influence of the modified combustion efficiency (MCE). While the influence of the fuel (hardwood for stove A and B, softwood for stove C) cannot be neglected, we highlight, from our set of experiments, the overriding importance of the MCE on both the EF of organic markers and their relative contribution to OA. Previous studies have already revealed a relationship between the MCE and characteristics of the mass spectral signature of the OA emissions (Jolleys et al., 2014; Bertrand et al., 2017) but the influence of the MCE on individual organic marker emissions is still virtually unknown. The MCE values for the log woodstoves (stove A and $\mathrm{B}$ ) range between 0.80 and 0.91 (Table 1), indicating that the combustion in these stoves is typically smoldering $(\mathrm{MCE}<0.9)$, but also highly variable. However, the pellet stove (stove C) shows little variability and produces a flaming type of combustion. The MCE values for the experiments conducted with this stove are 0.97 . More details regarding the burn variability can be found in Bertrand et al. (2017).

\subsubsection{Levoglucosan and other anhydrosugars}

The EFs of levoglucosan are in the range $26-249 \mathrm{mg} \mathrm{kg}^{-1}$ of fuel or $13-45 \%$ of the total POA mass concentration. Levoglucosan is emitted along with its two isomers: mannosan and galactosan. The EFs of mannosan are $4-20 \mathrm{mg} \mathrm{kg}^{-1}$ and represent an average fraction of the total POA mass concentration of $<4 \% \pm 2 \%(n=11)$. The EFs of galactosan are $0.5-10 \mathrm{mg} \mathrm{kg}^{-1}$ and contribute $<1 \%$ of the total POA mass concentration. Therefore, anhydrosugars represent $27-52 \%$ of the total POA mass concentration. For comparison, previous studies detailing the chemical composition of BBOA have typically reported lower contributions of anhydrosugars to the total POA mass concentration: $7 \%, n=6$; Fine et al., 2001, $7 \%, n=6$; Fine et al., 2002, $18 \%, n=7$; Fine et al., 2004, and $24 \%, n=3$; Schauer et al., 2001. However, the conditions and methods with which they sampled the emissions were different (on quartz fiber filters) with a dilution factor at least 10 times less than what is used in this study. This could result in a higher fraction of semi-volatile organic compounds (SVOCs) partitioning to the particulate phase, therefore increasing the overall OA mass, and thus decreasing the individual contribution of the markers.

Figure 4c shows the EF of levoglucosan and its contribution to the POA as a function of the MCE. The emission of levoglucosan correlates well with the MCE $\left(R^{2}=0.61\right.$, $n=11)$. Overall, emissions increase with lower MCE, while the actual contribution of levoglucosan to the total POA mass concentration decreases with lower MCE. Although no clear evidence can be drawn from previous studies (Fine et al., 2001, 2002, 2004; Schmidl et al., 2008a; Schauer et al., 2001), it is generally admitted that the contribution of levoglucosan to OA is higher for hardwood than for softwood combustions. As shown in Fig. 4e, such behavior is not observed here, which implies that the nature of the fuel is not the most important driver of the chemical composition of the emitted particles. We consider, therefore, that while smoldering combustions increase the emission of levoglucosan, this process also results in large emissions of a variety of other compounds (not identified nor quantified in our experiments) along with the anhydrosugars; the chemical composition of the resulting organic aerosol is thus more complex and the identified fraction by TAG-AMS of the total OA mass is lower. However, this substantial difference in the contribution of levoglucosan (from 40-50\% at the highest MCE down to $15 \%$ at the lowest MCE) is never considered in source profiles for source apportionment studies.

\subsubsection{Methoxyphenols}

Methoxyphenols include substituted guaiacol compounds such as vanillin, acetovanillone, vanillic acid, 3-guaiacylpropanol, and conyferyl aldehyde, as well as syringol and substituted syringols such as iso-eugenol, syringaldehyde, acetosyringone, syringyl acetone, propionyl syringol, syringic acid, methyl syringol, and synapyl aldehyde. The total EF of the methoxyphenols is between 7 and $174 \mathrm{mg} \mathrm{kg}^{-1}$. Syringyl acetone and vanillin are the most abundant compounds in their respective category with EFs ranging from 0.4 to $80 \mathrm{mg} \mathrm{kg}^{-1}$ and from 2 to $7 \mathrm{mg} \mathrm{kg}^{-1}$, respectively. As for levoglucosan, a strong correlation is observed between the total $\mathrm{EF}$ of methoxyphenols and the $\operatorname{MCE}\left(R^{2}=0.65, n=11\right.$, Fig. 4d), which indicates that smoldering conditions also favor the emission of this compound's class.

Methoxyphenols account for an important fraction of the POA, contributing $8-27 \%$ of the total POA mass concen- 
Table 2. pWLC contribution of the compounds to the total OA mass concentration at different times of the photo-oxidative process. This table only contains a list of selected compounds and average values. Data from all experiments are divided into seven bins of different integrated $\mathrm{OH}$ exposure intervals (from 0 to $9 \times 10^{6}$ molecules $\mathrm{cm}^{-3} \mathrm{~h}$ ) then averaged. A full list, with minimum and maximum values is also available in the Supplement.

\begin{tabular}{|c|c|c|c|c|c|c|c|}
\hline $\begin{array}{l}\text { Integrated } \mathrm{OH} \text { exposure } \\
\left(\text { molecules } \mathrm{cm}^{-3} \mathrm{~h}\right) \\
(n=\text { number of samples) }\end{array}$ & $\begin{array}{r}\text { Bin } 0 \\
0 \\
n=11 \\
\end{array}$ & $\begin{array}{r}\text { Bin } 1 \\
>0-5 \times 10^{5} \\
n=8 \\
\end{array}$ & $\begin{array}{r}\text { Bin } 2 \\
0.5-2 \times 10^{6} \\
n=12\end{array}$ & $\begin{array}{r}\text { Bin } 3 \\
2-4 \times 10^{6} \\
n=15\end{array}$ & $\begin{array}{r}\operatorname{Bin} 4 \\
4-6 \times 10^{6} \\
n=16\end{array}$ & $\begin{array}{r}\text { Bin } 5 \\
6-7.5 \times 10^{6} \\
n=7\end{array}$ & $\begin{array}{r}\text { Bin } 6 \\
7.5-9 \times 10^{6} \\
n=2 \\
\end{array}$ \\
\hline Total OA $\left(\mu \mathrm{g} \mathrm{m}^{-3}\right)(\min -\max )$ & 9-177 & $32-409$ & $13-715$ & $18-790$ & 19-774 & $18-504$ & $50-517$ \\
\hline Total contribution* (\% OA) & 52 & 20 & 20 & 14 & 10 & 13 & 9 \\
\hline \multicolumn{8}{|l|}{ Primary compounds (\% OA) } \\
\hline Levoglucosan & 29.2 & 9.5 & 9.6 & 6.3 & 4.6 & 6.0 & 3.5 \\
\hline Mannosan & 3.2 & 0.8 & 1.4 & 0.9 & 0.5 & 0.8 & 0.3 \\
\hline Fluorene & 0.15 & 0.06 & 0.07 & 0.05 & 0.03 & 0.05 & 0.08 \\
\hline Phenanthrene & 0.41 & 0.18 & 0.19 & 0.16 & 0.12 & 0.16 & 0.1 \\
\hline Anthracene & 0.08 & 0.04 & 0.03 & 0.02 & 0.02 & 0.02 & 0.02 \\
\hline Fluoranthrene & 0.22 & 0.07 & 0.14 & 0.13 & 0.1 & 0.2 & 0.14 \\
\hline Pyrene & 0.08 & 0.02 & 0.05 & 0.05 & 0.04 & 0.07 & 0.05 \\
\hline 1,2-Acenaphthylenone & 0.31 & 0.14 & 0.15 & 0.10 & 0.08 & 0.11 & 0.08 \\
\hline 9H-Fluoren-9-one & 0.03 & 0.01 & 0.02 & 0.02 & 0.01 & 0.02 & 0.02 \\
\hline Cyclopenta[d,e,f]phenanthrene & 0.03 & $<0.01$ & 0.01 & 0.01 & $<0.01$ & 0.01 & 0.01 \\
\hline 3-Guaiacylpropanol & 0.28 & 0.10 & 0.05 & 0.03 & 0.03 & 0.02 & 0.03 \\
\hline Conyferyl aldehyde & 0.29 & 0.07 & 0.04 & 0.03 & 0.02 & 0.02 & 0.02 \\
\hline Syringaldehyde & 2.7 & 1.7 & 1.1 & 0.7 & 0.5 & 0.6 & 0.6 \\
\hline Syringol & 1.43 & 1.08 & 0.59 & 0.25 & 0.16 & 0.19 & 0.13 \\
\hline Methylsyringol & 0.09 & 0.06 & 0.03 & 0.01 & 0.01 & 0.01 & 0.01 \\
\hline Acetosyringone & 0.41 & 0.20 & 0.11 & 0.06 & 0.05 & 0.05 & 0.05 \\
\hline Isoeugenol & 1.22 & 0.67 & 0.27 & 0.09 & 0.08 & 0.09 & 0.09 \\
\hline Syringyl acetone & 4.6 & 1.5 & 0.4 & 0.2 & 0.2 & 0.2 & 0.3 \\
\hline Propionyl syringol & 0.7 & 0.3 & 0.2 & 0.2 & 0.1 & 0.1 & 0.1 \\
\hline Synapyl aldehyde & 0.9 & 0.2 & 0.09 & 0.05 & 0.03 & 0.04 & 0.04 \\
\hline Palmitic acid & 0.28 & 0.09 & 0.15 & 0.09 & 0.06 & 0.11 & 0.04 \\
\hline Stearic acid & 0.11 & 0.05 & 0.06 & 0.04 & 0.03 & 0.05 & 0.02 \\
\hline \multicolumn{8}{|c|}{ Non-conventional primary compounds (\% OA) } \\
\hline Vanillin & 1.7 & 0.8 & 1.1 & 0.9 & 0.6 & 1.0 & 0.7 \\
\hline Acetovanillone & 0.29 & 0.13 & 0.17 & 0.14 & 0.14 & 0.14 & 0.1 \\
\hline Vanillic acid & 0.24 & 0.12 & 0.16 & 0.14 & 0.1 & 0.14 & 0.09 \\
\hline Syringic acid & 0.17 & 0.09 & 0.11 & 0.08 & 0.06 & 0.08 & 0.05 \\
\hline Pyrogallol & 0.02 & 0.02 & 0.03 & 0.02 & 0.02 & 0.02 & 0.01 \\
\hline Tyrosol & 0.36 & 0.16 & 0.17 & 0.12 & 0.09 & 0.12 & 0.15 \\
\hline \multicolumn{8}{|l|}{ Secondary compounds (\% OA) } \\
\hline 4-Nitrocatechol & 0.2 & 0.8 & 1.7 & 2.4 & 1.8 & 1.9 & 1.1 \\
\hline 4-Methyl-5-Nitrocatechol & 0.05 & 0.15 & 0.2 & 0.18 & 0.14 & 0.15 & 0.11 \\
\hline 3-Methyl-5-Nitrocatechol & 0.15 & 0.48 & 0.45 & 0.32 & 0.25 & 0.24 & 0.19 \\
\hline Vanillylmandelic acid & 0.02 & 0.08 & 0.06 & 0.04 & 0.03 & 0.03 & 0.02 \\
\hline Methylglutaric acid & $<0.01$ & 0.02 & 0.02 & 0.02 & 0.02 & 0.02 & 0.02 \\
\hline
\end{tabular}

* Sum from the contribution of all compounds averaged within the bins. 
tration. Unlike levoglucosan, the correlation between their relative contribution to POA and the MCE is more complex (Fig. 4f). We observe a similar upward trend when considering the experiments conducted with stove A and B only (hardwood, $R^{2}=0.41, n=8$ ). However, experiments conducted with stove $\mathrm{C}$ (softwood pellets) do not follow this trend. For methoxyphenols, the influence of the fuel is very well established with larger emissions of substituted guaiacols from softwood combustions, while hardwood combustion emissions contain a larger proportion of substituted syringols (Fine et al., 2001, 2002, 2004a, b). Here, as the quantification has been performed on the same set of compounds for all the experiments, we cannot exclude an underrepresentativeness of the substituted guaiacols towards the substituted syringol family.

\subsubsection{Other compounds}

Overall, the sum of PAHs, alkanes, and fatty acids accounts for $<8(1.6-7.6) \%$ of the total POA mass concentration. The EF of the individual PAHs vary between $3 \mu \mathrm{g} \mathrm{kg}^{-1}$ and $4 \mathrm{mg} \mathrm{kg}^{-1}$, with combined amounts between 2 and $14 \mathrm{mg} \mathrm{kg}^{-1}$. The relative contributions of the PAHs to the total POA mass concentration vary between 1.4 and $6.4 \%$. Phenanthrene and fluoranthrene are the most dominant as they represent over one-third of the total PAH contributions. The total EFs of the alkanes $\left(\mathrm{C}_{18}-\mathrm{C}_{27}\right)$ vary between 0.5 and $2 \mathrm{mg} \mathrm{kg}^{-1}$. They represent between 0.04 and $0.73 \%$ of the total POA mass concentration. Four fatty acids including the saturated acids (palmitic acid and stearic acid) and the unsaturated acids (palmitoleic acid and oleic acid) were identified. Their total EFs are similar to the n-alkanes, and they contribute between 0.03 and $1.3 \%$ of the total POA mass concentration. As for levoglucosan, we observe an increase in their contribution to the total POA mass concentration as a function of the MCE (see Fig. S2 in the Supplement). Other compounds reported in this manuscript account for a negligible fraction of the primary OA emission, with the exception of experiment 8 (stove B) where they (mainly the nitrocatechols, see Sect. 3.2) contribute $<3 \%$ of the total POA mass concentration.

\subsection{Effect of atmospheric aging on the chemical fingerprint of $\mathrm{OA}$}

The molecular fingerprint of the BBOA undergoes important modifications during aging. By highlighting the differences observed between a sample of fresh and aged biomass burning emissions, Fig. 5 illustrates the impact of such aging on the molecular fingerprint of the emissions. Considering that such fast modifications can generate significant biases in our ability to properly apportion the biomass burning source in the ambient atmosphere, quantitative data on the chemical changes in the molecular signature are required. The contributions of the most relevant markers to the total OA mass concentration at different stages of the photo-oxidative process are also reported in Table 2. A more exhaustive table is also available in the Supplement (Table S4). Although TAGAMS samples are collected and analyzed approximately at the same time (after lights on) between the experiments, the integrated $\mathrm{OH}$ exposure is not homogeneous. Therefore, data are divided into seven bins of different integrated $\mathrm{OH}$ exposure intervals (Fig. 6; from 0 to $9 \times 10^{6}$ molecules $\mathrm{cm}^{-3} \mathrm{~h}$ ). The intervals are set to best reflect the evolution of the compounds. Note, while it is possible that differences in the composition of the primary emissions can influence the SOA composition, we have not found significant differences in the evolution of the individual markers. In this section, we therefore consider all aging experiments from the three stoves. EFs of the molecular markers at an integrated $\mathrm{OH}$ exposure of $5 \times 10^{6}$ molecules $\mathrm{cm}^{-3} \mathrm{~h}$ for each experiment are reported in Table S3 in the Supplement.

Figure 6 further illustrates the quantitative modification of the chemical fingerprint during the aging process for one experiment (experiment 2). In this example, while the quantified markers represent $32 \%$ of the total POA mass concentration, only $4.5 \%$ of the total OA mass concentration measured by HR-ToF-AMS is identified by the time the experiment reaches an integrated $\mathrm{OH}$ exposure of $5 \times 10^{6}$ molecules $\mathrm{cm}^{-3} \mathrm{~h}$. This result can be generalized since $<10 \%$ of the total POA mass concentration is quantified at the molecular level after the photo-oxidative process. This can be explained by the nature of the emissions present at this stage of the experiment. Due to the oxidative mechanisms taking place, aged OA emissions contain a large amount of high molecular weight, low volatility, and highly oxygenated compounds (Donahue et al., 2011; Ng et al., 2011) with multiple isomers. This is reflected in the modification of the $\mathrm{O}: \mathrm{C}$ ratio (from 0.45 to 0.65 ). Many of these more oxidized and highly functionalized compounds cannot be easily identified by the methods used here, either because they do not elute from the TAG-AMS or because their mass spectra are not present in the NIST libraries.

We look at the evolution of the absolute concentrations of the compounds and their enhancement ratios (ER). The ER is defined as the ratio between pWLC concentration measured in the particle phase at a time $t$ and the concentration in the particle phase measured at $t_{0}$ or before lights on. A compound with an ER $>1$ would indicate the compound is formed during aging. An ER $<1$ relates to the decay of a compound (i.e., if $\mathrm{ER}=0.2,80 \%$ of the mass of the compound is lost during aging). We can then classify the compounds within three categories:

$$
\begin{aligned}
& \text { - primary compounds }(\mathrm{ER}<1) \\
& \text { - non-conventional primary compounds }(1<\mathrm{ER}<4) \\
& \text { - secondary compounds }(\mathrm{ER}>10)
\end{aligned}
$$

Figure 7 shows the ERs of all compounds in their respective categories. Primary compounds are compounds emitted 
(a)

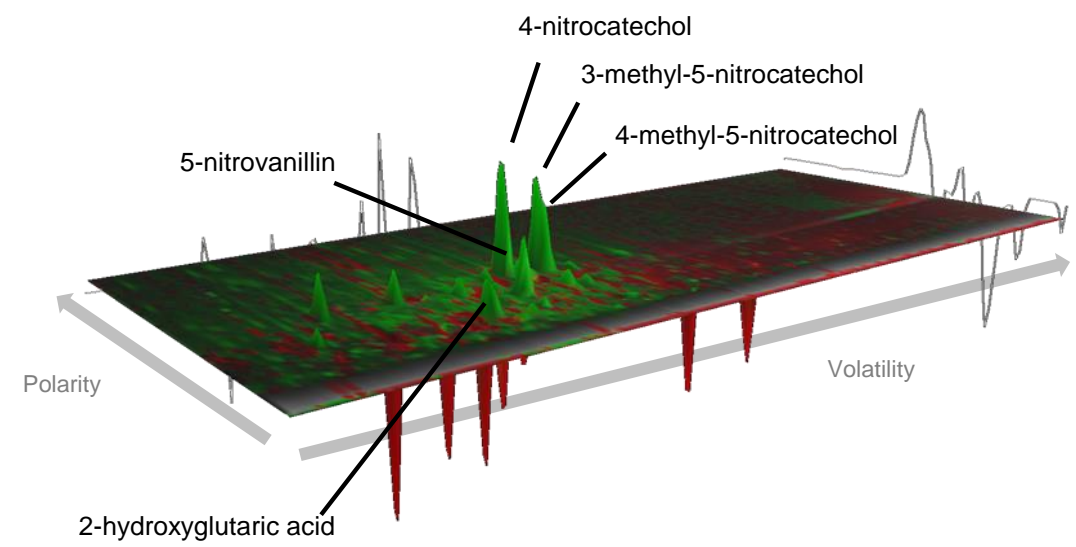

(b)

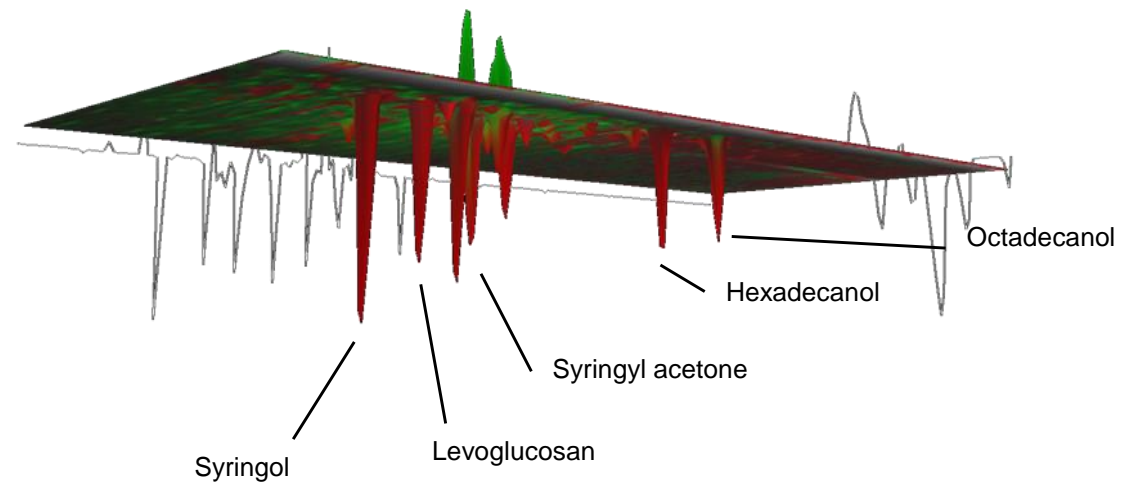

Figure 5. Overview of the changes occurring in the chemical fingerprint at the molecular level of biomass burning organic aerosol (BBOA) during atmospheric aging. Organic markers forming (green) or decaying (red) during aging. The figure is a three-dimensional representation of the difference in intensity of the peaks (normalized to the signal of the internal standards) calculated between aged (integrated OH exposure of $5 \times 10^{6}$ molecules $\mathrm{cm}^{-3} \mathrm{~h}$ ) and fresh samples. The samples were collected on quartz fiber filters and analyzed with GC $\times$ GC EI-HR-ToF-MS (see SI). Panel (a) is viewed from the top and (b) from the bottom.

during the combustion and whose concentration in the atmospheric chamber is found to decrease during aging. The non-conventional primary compounds are compounds emitted along with other conventional primary compounds during combustion but whose concentration is found to increase during aging. Note that as the concentrations of the nonconventional primary compounds increase more slowly than $\mathrm{OA}$, their relative contributions to the total OA mass concentration slightly decreases during the aging phase. The secondary compounds are compounds principally found after lights on. In certain experiments, these were also detected in minor amounts in the primary emissions. We distinguish them from the non-conventional primary compounds by the relative amount formed during aging (over 10 times the concentration measured in the primary emissions).

\subsubsection{Primary compounds}

The identified primary compounds initially represent $48 \%$ of the total POA mass concentration but $<8 \%$ of the total OA mass concentration after 4-6h of atmospheric aging (bin
4). Levoglucosan and syringyl acetone are the most abundant compounds of this category. Other compounds include the isomers of levoglucosan, mannosan, and galactosan, as well as the PAHs, alkanes, and the following methoxyphenols: 3guaiacylpropanol, conyferyl aldehyde, syringol, iso-eugenol, syringaldehyde, acetosyringone, propionyl syringol, methyl syringol, and synapyl aldehyde.

Before lights on, levoglucosan contributes on average $30 \%$ of the total OA mass concentration. Its contribution decreases to $4.5 \%$ after approximately $4-6 \mathrm{~h}$ of atmospheric aging, i.e., by a factor of 6.6. Within the first hour, its contribution to OA is decreased by a factor of 3 (Fig. 8). The mean ER of levoglucosan is $0.6(0.4-0.8)$. The decrease in mannosan is on a similar scale, contributing $<4 \%$ of the total OA before lights on and then decreasing to $0.5 \%$ after aging, i.e., decreasing by a factor of 7 . Its mean ER is also $0.6(0.4-0.8)$.

Before lights on, syringyl acetone contributes $4.7 \%$ of the total OA mass concentration. Its contribution decreases to $0.2 \%$ after aging (a decrease by a factor of $23.5 \%$ ). Within 


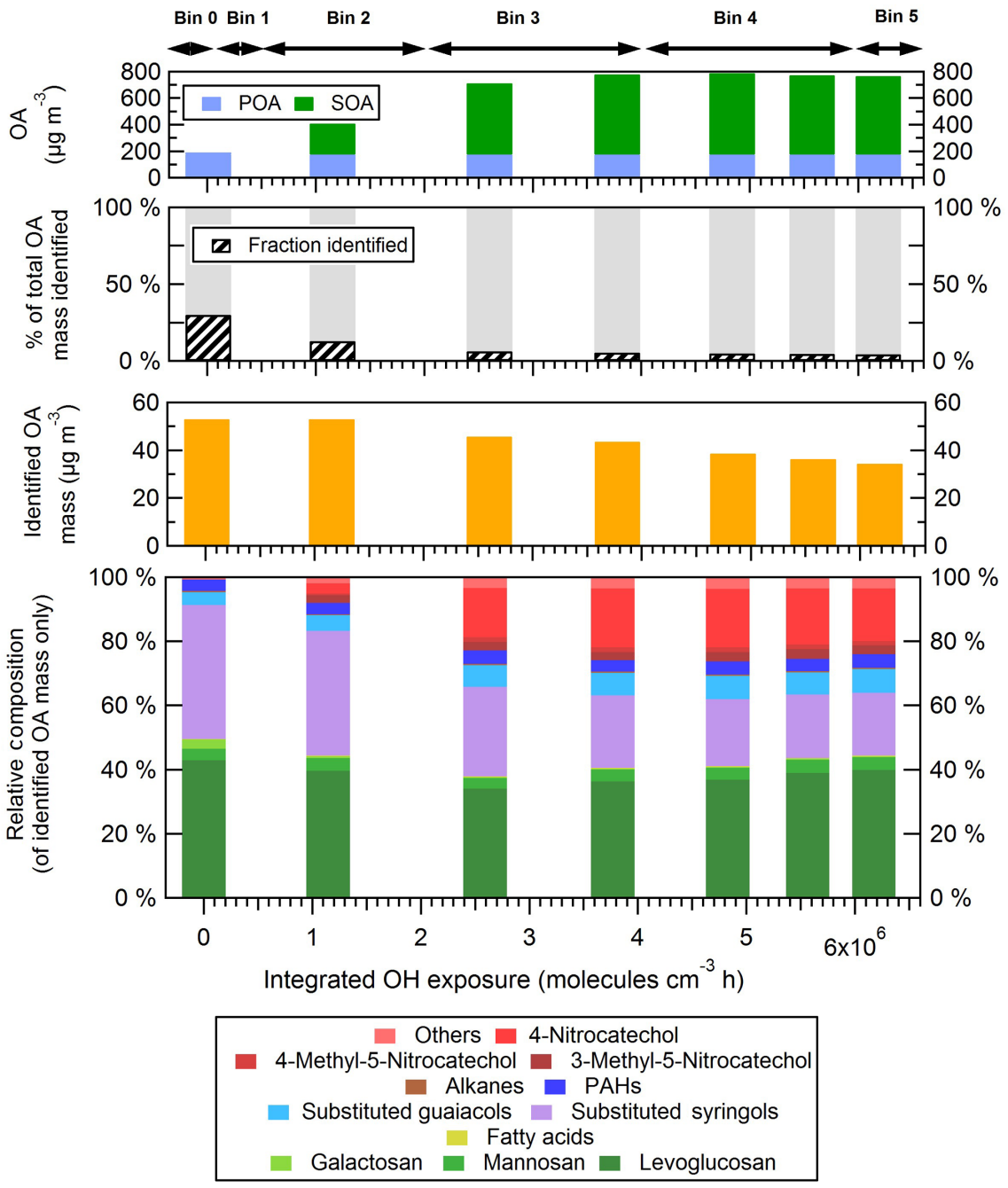

Figure 6. Typical evolution of the chemical fingerprint of the organic aerosol emitted by biomass burning during atmospheric aging (Exp. 2, stove A). "Identified OA mass" refers to the OA mass concentration whose molecular composition is resolved by TAG-AMS.

$1 \mathrm{~h}$ of atmospheric aging, its contribution to the total OA mass concentration has decreased by a factor of 5 . Its mean ER is $0.3(0.1-0.7)$. The contribution of the other identified methoxyphenols to the total OA mass concentration decrease by an average factor of 17 after 4-6h of atmospheric aging (as high as a factor of 43 for synapyl aldehyde and as low as 6 for syringaldehyde).

The PAHs and alkanes show a more moderate decrease. Their contribution to the total OA mass concentration decreases by approximately 2 to 5 times after $4-6 \mathrm{~h}$ of atmospheric aging. The high molecular weight PAHs are an exception. Benzofluoranthene and other five-ring PAHs are observed to decrease by a factor $>10$ after $4-6 \mathrm{~h}$ of atmospheric aging.

The rate at which these compounds decrease is of particular interest. Many serve as molecular markers in source apportionment studies and are as such implicitly assumed to not oxidize or volatilize. If they are not stable, these mark- ers will introduce a bias in the results and lead to an underestimation of the contribution of biomass burning in favor of other sources including the secondary fraction. Previous studies have examined the effective rate constant for the reaction of these compounds with $\mathrm{OH}$ (Lambe et al., 2009; Hennigan et al., 2010, 2011; Kessler et al., 2010; Lai et al., 2014) at ambient temperature, and the rate at which levoglucosan decreases here is consistent with their results (at $2{ }^{\circ} \mathrm{C}$ ). However, we note that our results ignore the semi-volatile nature of many of these compounds and likely wall losses. As demonstrated by May et al. (2012) and Zhang et al. (2015), ignoring wall losses can result in an underestimation of the compound concentration measured in the chamber as much as by a factor of 4 . Therefore, the $k_{\mathrm{OH}}$ rate constant derived from these results must be regarded with caution. This is addressed in further detail in Bertrand et al. (2018). 


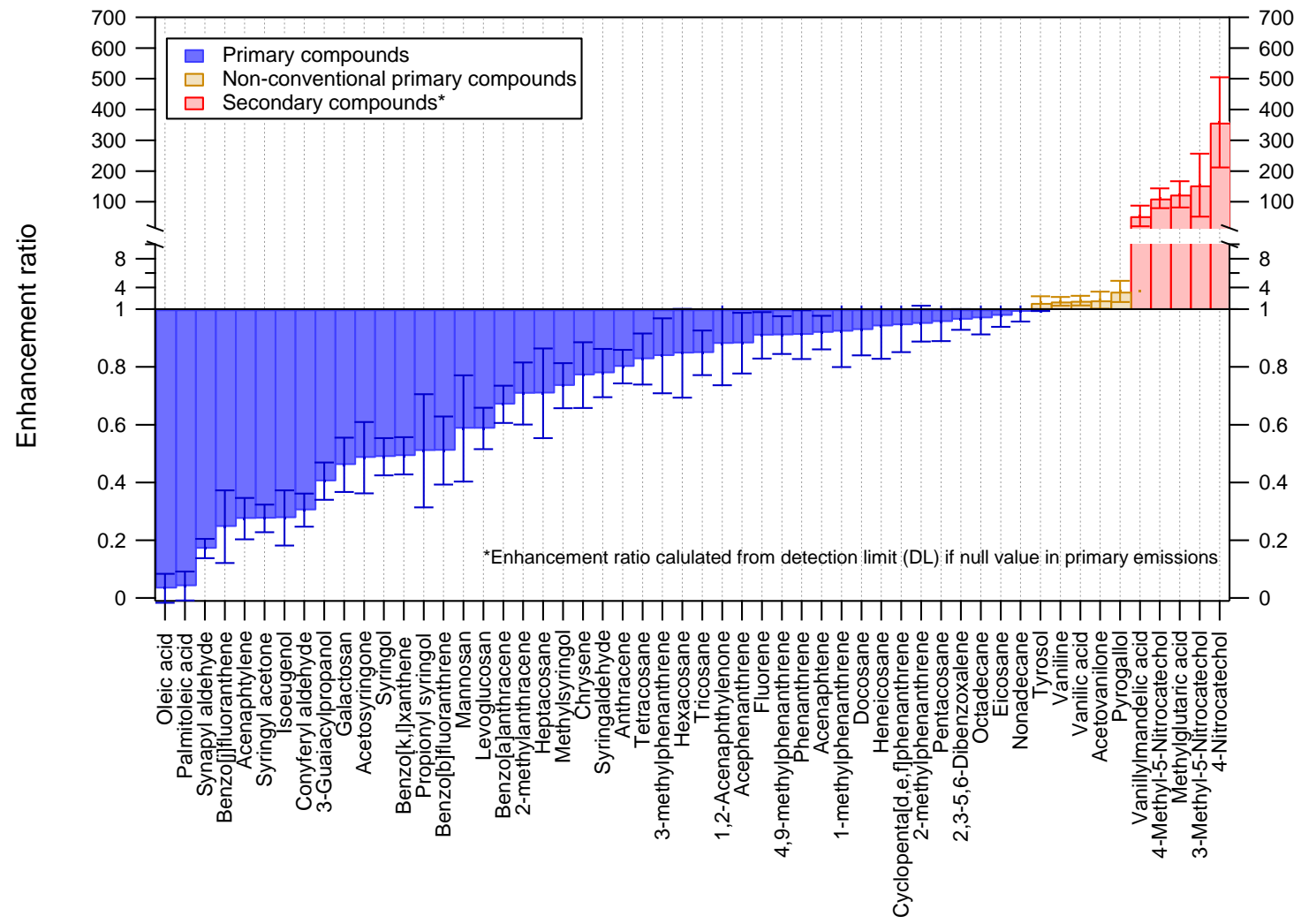

Figure 7. Mean enhancement ratios (ERs) of individual compounds in biomass burning emissions. The ER is defined as the pWLC concentration measured in the particle phase within a time range corresponding to an integrated $\mathrm{OH}$ exposure of $4-6 \times 10^{6} \mathrm{molecules} \mathrm{cm}^{-3} \mathrm{~h}$ (bin 4, Fig. 6) and divided by the concentration in the particle phase measured at $t_{0}$ (i.e., before lights on). An ER of 0.8 means a loss of $20 \%$ during aging after pWLC. Note that for the secondary compounds (red) observed after the start of the photo-oxidative process only, the ERs are calculated using the detection limit. Error bars show the standard deviation derived from all experiments.

\subsubsection{Non-conventional primary compounds}

This category includes mainly methoxyphenols such as vanillic acid, vanillin, acetovanillone, and syringic acid, as well as some less known compounds: tyrosol and pyrogallol. Their contribution to the primary emissions is not significant (on average $<3 \%$ of the total POA mass concentration in total). Unlike the other primary compounds emitted during combustion, their pWLC concentration is found to increase during aging. Fortenberry et al. (2018) observed a similar trend for vanillin. As most of these compounds are detected both in the gas and particle phase of the emissions (Bruns et al., 2017; Schauer et al., 2001), with the smaller fraction detected in the particle phase of the emissions, it is possible that their increase is partly a result of the partitioning effect. A significant increase in the OA mass after lights on as observed in these experiments could drive a larger fraction into the particle phase. However, it is likely that this effect would be reduced by the vapor wall loss also occurring, which has been demonstrated to be significant by other authors (Zhang et al., 2015; La et al., 2016; Trump et al., 2016; Ye et al., 2016). Therefore, the other most sensible hypothesis is that these compounds are formed during the oxidation process. Several experiments have been conducted on the heterogeneous and gas-phase reactivity of methoxyphenols with atmospheric oxidants $\left(\mathrm{OH}, \mathrm{NO}_{3}\right.$; Net et al., 2011; Lauraguais et al., 2012; Yee et al., 2013). Typically, they react to first form intermediate products with a structure akin to the initial methoxyphenol. For example, Liu et al. (2012) reported vanillin and vanillic acid as by-products of the reaction of the methoxyphenol conyferyl aldehyde in the presence of the nitrate radical. A mechanism of the formation of vanillin from larger lignin decomposition products was also described by Wong et al. (2010).

The mean ER of vanillic acid is 2.2 (1.4-3.8). The compound represents 0.1 to $0.3 \%$ of the total OA mass concentration at its peak concentration during aging (Fig. 8). This is within the same range of proportions observed before lights on. Similar ER are obtained for vanillin and acetovanillone (2.1 and 2.2, respectively). Syringic acid and tyrosol show a slightly more moderate mean ER of 1.9 and the mean ER of the pyrogallol is $3.5(2-5)$. 

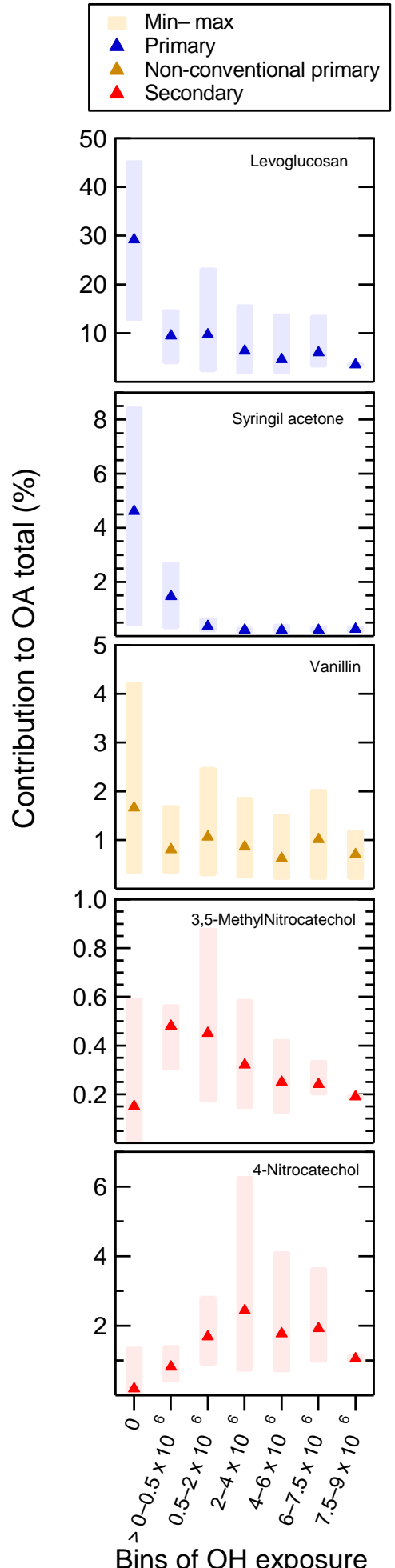

Figure 8. Evolution of the contribution of several markers to the $\mathrm{OA}_{(t)}$ mass concentration at different time points in the photooxidation process. The marker represents the mean value over all experiments within a specific range of integrated $\mathrm{OH}$ exposure. The box includes the minimum and maximum within the same range.

\subsubsection{Secondary compounds}

The identified secondary compounds include nitro-aromatic compounds such as 4-nitrocatechol (4-NC) and its methylated derivatives, 4-methyl-5-nitrocatechol (4M5NC) and 3methylated-5-nitrocatechol (3M5NC), as well as methylglutaric acid and vanillylmandelic acid. After $4-6 \mathrm{~h}$ of atmospheric aging, these compounds contribute $2.5 \%$ of the total OA mass concentration.

Nitrocatechols are the most abundant secondary compounds detected. Iinuma et al. (2010), Kelly et al. (2010), and Finewax et al. (2018) demonstrated their formation through the oxidation of cresol in the presence of $\mathrm{NO}_{x}$. The aerosol formation of nitrocatechols varies between 7 and $65 \mathrm{mg} \mathrm{kg}^{-1}$ for 4-NC, between 0.3 and $6 \mathrm{mg} \mathrm{kg}^{-1}$ for $4 \mathrm{M} 5 \mathrm{NC}$, and between 0.4 and $10 \mathrm{mg} \mathrm{kg}^{-1}$ for $3 \mathrm{M} 5 \mathrm{NC}$. In the experiments where $4-\mathrm{NC}$ is detected in the primary emission $(<0.2 \%$ of total OA), the ER averages at 80 (15-260). For experiment 8 only, we observe a substantial amount of 4-NC in the primary emissions (>1\% of the POA mass concentration). The ER of the compound is 6 in this case. With regard to the alkylated nitrocatechols, 5 of the 11 experiments present trace levels of $4 \mathrm{M} 5 \mathrm{NC}$ in the primary emissions. The ER averages at 17 ( 3 to 50 ). The average ER for 3M5NC is 14 (3 to 45). The concentrations of these compounds increase within the first $1-2 \mathrm{~h}$ of atmospheric aging, and contribute to as high as 5$6 \%$ of the total OA mass concentration in the case of 4-NC (Fig. 8), and up to 0.4 and $0.8 \%$ for $3 \mathrm{M} 5 \mathrm{NC}$ and $4 \mathrm{M} 5 \mathrm{NC}$, respectively. The concentration of $3 \mathrm{M} 5 \mathrm{NC}$ decreases soon after the initial peaking (by a factor of 2 to 3 near the end of the experiment), whereas the concentrations of 4-NC and 4M5NC remain stable. We hypothesize that the formation and loss processes compete, especially in the case of these compounds.

Nitro-aromatic compounds have been observed at sites impacted by biomass burning before (Iinuma et al., 2010; Claeys et al., 2012; Kitanovski et al., 2012, 2014; Mohr et al., 2013; Kahnt et al., 2013; Frka et al., 2016; Gaston et al., 2016) at concentration levels typically two orders of magnitude lower than that of levoglucosan (4$\mathrm{NC} / \mathrm{LG} \approx 0.01-0.1, \mathrm{MNC} / \mathrm{LG} \approx 0.01-0.08$ ). Here, the 4$\mathrm{NC} / \mathrm{LG}$ and MNC / LG ratios vary from 0.25 to 0.5 and 0.06 to 0.15 , respectively. We hypothesize that the higher levels of 4-nitrocatechol emissions found in the chamber are the result of a high concentration of $\mathrm{NO}_{x}$ (Table 1 ; in a range of 50 to $252 \mathrm{ppb}$, compared to $40-50 \mathrm{ppb}$ in areas heavily impacted by biomass burning (Brulfert et al., 2005; Sandradewi et al., 2008). Experiments conducted at higher $\mathrm{NO}_{x}$ concentrations (i.e., experiments $9-11$ with stove $\mathrm{C}$; see Table 1, $\mathrm{THC} / \mathrm{NO}_{x} \approx 5$, cresol / $\mathrm{NO}_{x}<0.005$ ) show the highest contribution of 4-NC to the OA mass concentration (3-6\%).

The EI mass spectra of 4-nitrocatechol and the alkylated nitrocatechols (without derivatization) are dominated by the ion $\mathrm{C}_{6} \mathrm{H}_{5} \mathrm{NO}_{4}^{+}(m / z 155)$ and $\mathrm{C}_{6} \mathrm{H}_{2} \mathrm{NO}_{4}^{+}(m / z 152)$, respectively, which are detected with the HR-ToF-AMS. Fig- 
(a)

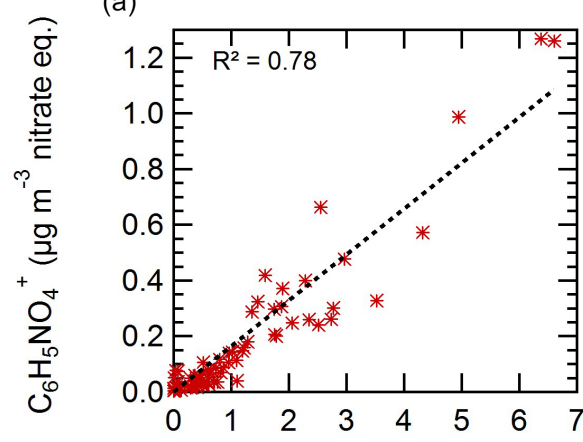

(b)
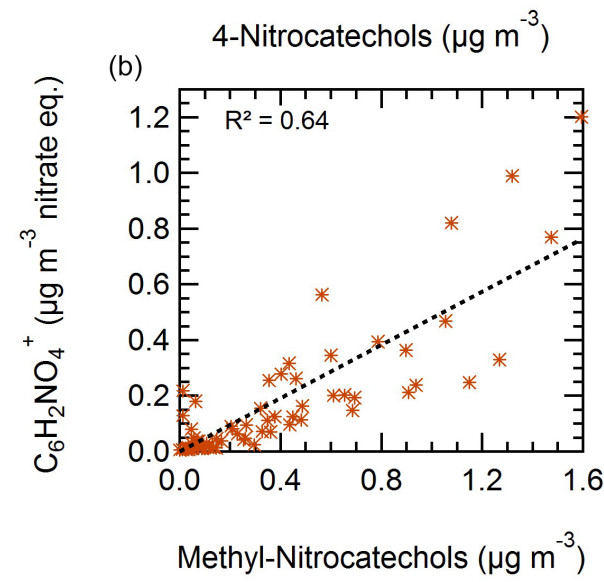

Figure 9. HR-ToF-AMS measurements against TAG-AMS measurements. $\mathrm{C}_{6} \mathrm{H}_{5} \mathrm{NO}_{4}^{+}(m / z$ 155.022) vs. 4-nitrocatechol (a), and $\mathrm{C}_{6} \mathrm{H}_{2} \mathrm{NO}_{4}^{+}(\mathrm{m} / z$ 151.098) vs. alkylated nitrocatechols (3methyl-5-nitrocatechol and 4-methyl-5-nitrocatechol) (b), during the aging of biomass burning emissions. Intensities of $\mathrm{C}_{6} \mathrm{H}_{5} \mathrm{NO}_{4}^{+}$ $\left(m / z\right.$ 155.022) and $\mathrm{C}_{6} \mathrm{H}_{2} \mathrm{NO}_{4}^{+}(m / z$ 151.098) from the HR-ToFAMS data are expressed here in $\mu \mathrm{g} \mathrm{m}^{-3}$ nitrate equivalent, which reflects the peak intensities and not an actual concentration. A dedicated calibration of the HR-ToF-AMS is needed.

ure 9 shows the intensity of the fragments from HR-ToFAMS measurements (expressed in $\mu \mathrm{g} \mathrm{m}^{-3}$ nitrate equivalents) against the concentrations of the nitrocatechol compounds measured by the TAG-AMS. The best correlation is observed for 4-nitrocatechol $\left(R^{2}=0.78\right)$. For alkylated nitrocatechols the correlation is slightly weaker $\left(R^{2}=0.64\right)$, most probably due to the contribution of different isomers. While a proper calibration is needed, such relationships indicate that these two ions $\left(\mathrm{C}_{6} \mathrm{H}_{5} \mathrm{NO}_{4}^{+}\right.$and $\left.\mathrm{C}_{6} \mathrm{H}_{2} \mathrm{NO}_{4}^{+}\right)$can potentially be considered as suitable tracers of nitrocatechol compounds in AMS measurements and could offer interesting perspectives for the quantification of secondary BBOA in ambient atmosphere. However, and because of possible interferences from other aerosol sources, this assumption must be confirmed with more complex organic matrices.

Finally, this third category also includes less often reported compounds. They, however, represent only a small fraction of the total OA mass concentration. At its peak, the methylglutaric acid contributes $<0.05 \%$. The aerosol formation varies between 0.01 and $2 \mathrm{mg} \mathrm{kg}^{-1}$. For the majority of the experiments, this compound is detected only during aging. Only two experiments show traces of the compound before lights on. Their ERs are 9 and 15, respectively. The vanillylmandelic acid contributes as much as $0.2 \%$ of the total OA. The EFs for aged emissions vary between 0.04 and $1 \mathrm{mg} \mathrm{kg}^{-1}$. The compound is detected in the primary emission of all experiments but its enhancement ratio is $>10$.

\section{Conclusions}

We investigate the influence of the combustion efficiency and atmospheric aging on the chemical fingerprint of the OA emitted by biomass burning by means of a TAG-AMS. We provide a detailed quantitative analysis of the evolution of the contribution of 71 markers to the OA mass from fresh to aged emission. We draw the following conclusions:

- The emission factors of the individual organic markers are mostly driven by the MCE. Smoldering combustion increases the $\mathrm{EF}$ of the reported compounds. Within the experiments conducted with the same fuel, the contribution of the markers to the total POA mass concentration also varies according to the MCE (i.e., lower contribution at smoldering conditions). This indicates that smoldering combustion produces OA emissions with a more complex composition. The contribution of levoglucosan for instance varies from 40-50\% at the highest MCE down to $15 \%$ at the lowest MCE.

- The resolved fraction of fresh woodstove emissions by TAG-AMS is on average $52 \%$, but dramatically decreases with photochemical aging to $<10 \%$ after an integrated $\mathrm{OH}$ exposure of $5 \times 10^{6}$ molecules $\mathrm{cm}^{-3} \mathrm{~h}$. The majority of secondary compounds thus remain unidentified.

- The contribution of a variety of tracers to the total OA mass concentration evolves substantially during aging. We establish ratios for all reported compounds as a function of the photo-oxidative processing time. For instance, the contribution by levoglucosan, the concentration of which decreases by approximately $40 \%$ during aging, is $<10 \%$ to the total OA mass concentration at the end of the experiment against an average contribution of $30 \%$ for the fresh emissions.

- Nitro-aromatic compounds such as 4-nitrocatechol, 4methyl-5-nitrocatechol (4,5-MNC) and 3-methylated-5nitrocatechol are formed during aging. They can contribute significantly to the total OA mass concentration (2-4\%), and thus may serve as aged biomass burning tracers in future source apportionment studies. 
These data will serve to improve our ability to properly apportion the biomass burning source in the ambient atmosphere. Already, source apportionment studies reveal a large fraction of the aged OA originate from modern sources (i.e., non-fossil fuel sources). Thus, the secondary compounds highlighted in this study should be evaluated to serve as potential tracers of the aged biomass burning emissions. The lack of stability of the primary compounds in the context of source apportionment and how this might result in an underestimated contribution of BBOA should also be further examined.

Data availability. The datasets are available upon request to the corresponding authors.

\section{The Supplement related to this article is available online at https://doi.org/10.5194/acp-18-7607-2018-supplement.}

Competing interests. The authors declare that they have no conflict of interest.

Acknowledgements. This work was supported by the French Environment and Energy Management Agency (ADEME) project VULCAIN (grant number: 1562C0019). AB also acknowledges ADEME and the Provence-Alpes-Côte d'Azur (PACA) region for their support. CNJ and AHG acknowledge support from NSF AGS award 1524211 and NOAA award NA16OAR4310107. The Paul Scherrer Institute acknowledges the financial contribution by the SNF project WOOSHI and the IPR-SHOP SNF starting grant.

Edited by: Steven Brown

Reviewed by: two anonymous referees

\section{References}

Andreae, M. O. and Merlet, P.: Emission of trace gases and aerosols from biomass burning, Global Biogeochem. Cy., 15, 955-966, https://doi.org/10.1029/2000GB001382, 2001.

Barmet, P., Dommen, J., DeCarlo, P. F., Tritscher, T., Praplan, A. P., Platt, S. M., Prévôt, A. S. H., Donahue, N. M., and Baltensperger, U.: $\mathrm{OH}$ clock determination by proton transfer reaction mass spectrometry at an environmental chamber, Atmos. Meas. Tech., 5, 647-656, https://doi.org/10.5194/amt-5-647-2012, 2012.

Bertrand, A., Stefenelli, G., Bruns, E. A., Pieber, S. M., TemimeRoussel, B., Slowik, J. G., Prévôt, A. S. H., Wortham, H., El Haddad, I., and Marchand, N.: Primary emissions and secondary aerosol production potential from woodstoves for residential heating: Influence of the stove technology and combustion efficiency, Atmos. Environ., 169, 65-79, https://doi.org/10.1016/j.atmosenv.2017.09.005, 2017.
Bertrand, A., Stefenelli, G., Pieber, S. M., Bruns, E. A., TemimeRoussel, B., Slowik, J. G., Wortham, H., Prévôt, A. S. H., El Haddad, I., and Marchand, N.: Influence of the vapor wall loss on the degradation rate constants in chamber experiments of levoglucosan and other biomass burning markers, Atmos. Chem. Phys. Discuss., https://doi.org/10.5194/acp-2018-40, in review, 2018.

Bonvalot, L., Tuna, T., Fagault, Y., Jaffrezo, J.-L., Jacob, V., Chevrier, F., and Bard, E.: Estimating contributions from biomass burning, fossil fuel combustion, and biogenic carbon to carbonaceous aerosols in the Valley of Chamonix: a dual approach based on radiocarbon and levoglucosan, Atmos. Chem. Phys., 16, 13753-13772, https://doi.org/10.5194/acp-16-137532016, 2016.

Brulfert, G., Chemel, C., Chaxel, E., and Chollet, J. P.: Modelling photochemistry in alpine valleys, Atmos. Chem. Phys., 5, 23412355, https://doi.org/10.5194/acp-5-2341-2005, 2005.

Bruns, E. A., Krapf, M., Orasche, J., Huang, Y., Zimmermann, R., Drinovec, L., Močnik, G., El-Haddad, I., Slowik, J. G., Dommen, J., Baltensperger, U., and Prévôt, A. S. H.: Characterization of primary and secondary wood combustion products generated under different burner loads, Atmos. Chem. Phys., 15, 2825-2841, https://doi.org/10.5194/acp-15-2825-2015, 2015.

Bruns, E. A., Slowik, J. G., El Haddad, I., Kilic, D., Klein, F., Dommen, J., Temime-Roussel, B., Marchand, N., Baltensperger, U., and Prévôt, A. S. H.: Characterization of gas-phase organics using proton transfer reaction time-of-flight mass spectrometry: fresh and aged residential wood combustion emissions, Atmos. Chem. Phys., 17, 705-720, https://doi.org/10.5194/acp-17-7052017, 2017.

Canagaratna, M. R., Jimenez, J. L., Kroll, J. H., Chen, Q., Kessler, S. H., Massoli, P., Hildebrandt Ruiz, L., Fortner, E., Williams, L. R., Wilson, K. R., Surratt, J. D., Donahue, N. M., Jayne, J. T., and Worsnop, D. R.: Elemental ratio measurements of organic compounds using aerosol mass spectrometry: characterization, improved calibration, and implications, Atmos. Chem. Phys., 15, 253-272, https://doi.org/10.5194/acp-15-253-2015, 2015.

Claeys, M., Vermeylen, R., Yasmeen, F., Gómez-González, Y., Chi, X., Maenhaut, W., Mészáros, T., and Salma, I.: Chemical characterisation of humic-like substances from urban, rural and tropical biomass burning environments using liquid chromatography with UV/vis photodiode array detection and electrospray ionisation mass spectrometry, Environ. Chem., 9, 273-284, https://doi.org/10.1071/EN11163, 2012.

DeCarlo, P. F., Kimmel, J. R., Trimborn, A., Northway, M. J., Jayne, J. T., Aiken, A. C., Gonin, M., Fuhrer, K., Horvath, T., Docherty, K. S., Worsnop, D. R., and Jimenez, J. L.: Field-Deployable, High-Resolution, Time-ofFlight Aerosol Mass Spectrometer, Anal. Chem., 78, 8281-8289, https://doi.org/10.1021/ac061249n, 2006.

Donahue, N. M., Epstein, S. A., Pandis, S. N., and Robinson, A. L.: A two-dimensional volatility basis set: 1. organic-aerosol mixing thermodynamics, Atmos. Chem. Phys., 11, 3303-3318, https://doi.org/10.5194/acp-11-3303-2011, 2011.

Drinovec, L., Močnik, G., Zotter, P., Prévôt, A. S. H., Ruckstuhl, C., Coz, E., Rupakheti, M., Sciare, J., Müller, T., Wiedensohler, A., and Hansen, A. D. A.: The "dual-spot" Aethalometer: an improved measurement of aerosol black carbon with realtime loading compensation, Atmos. Meas. Tech., 8, 1965-1979, https://doi.org/10.5194/amt-8-1965-2015, 2015. 
El Haddad, I., Marchand, N., Dron, J., Temime-Roussel, B., Quivet, E., Wortham, H., Jaffrezo, J. L., Baduel, C., Voisin, D., Besombes, J. L., and Gille, G.: Comprehensive primary particulate organic characterization of vehicular exhaust emissions in France, Atmos. Environ., 43, 6190-6198, https://doi.org/10.1016/j.atmosenv.2009.09.001, 2009.

European Standards: European Standards EN 15234-2 Solid biofuels - Fuel quality assurance - Part 2: Wood pellets for non-industrial use, available at: https://www.en-standard.eu/csnen-15234-2-solid-biofuels-fuel-quality-assurance-part-2 (last access: 20 July 2017), 2012.

Fine, P. M., Cass, G. R., and Simoneit, B. R. T.: Chemical Characterization of Fine Particle Emissions from Fireplace Combustion of Woods Grown in the Northeastern United States, Environ. Sci. Technol., 35, 2665-2675, https://doi.org/10.1021/es001466k, 2001.

Fine, P. M., Cass, G. R., and Simoneit, B. R. T.: Chemical Characterization of Fine Particle Emissions from the Fireplace Combustion of Woods Grown in the Southern United States, Environ. Sci. Technol., 36, 1442-1451, https://doi.org/10.1021/es0108988, 2002.

Fine, P. M., Cass, G. R., and Simoneit, B. R.: Chemical characterization of fine particle emissions from the wood stove combustion of prevalent United States tree species, Environ. Eng. Sci., 21, 705-721, 2004.

Finewax, Z., de Gouw, J. A., and Ziemann, P. J.: Identification and Quantification of 4-Nitrocatechol Formed from $\mathrm{OH}$ and $\mathrm{NO}$ Radical-Initiated Reactions of Catechol in Air in the Presence of NO: Implications for Secondary Organic Aerosol Formation from Biomass Burning, Environ. Sci. Technol., 52, 1981-1989, https://doi.org/10.1021/acs.est.7b05864, 2018.

Fortenberry, C. F., Walker, M. J., Zhang, Y., Mitroo, D., Brune, W. H., and Williams, B. J.: Bulk and molecular-level characterization of laboratory-aged biomass burning organic aerosol from oak leaf and heartwood fuels, Atmos. Chem. Phys., 18, 2199 2224, https://doi.org/10.5194/acp-18-2199-2018, 2018.

Fraser, M. P., Cass, G. R., and Simoneit, B. R. T.: Particulate organic compounds emitted from motor vehicle exhaust and in the urban atmosphere, Atmos. Environ., 33, 2715-2724, https://doi.org/10.1016/S1352-2310(98)00311-2, 1999.

Frka, S., Šala, M., Kroflič, A., Huš, M., Čusak, A., and Grgić, I.: Quantum Chemical Calculations Resolved Identification of Methylnitrocatechols in Atmospheric Aerosols, Environ. Sci. Technol., 50, 5526-5535, https://doi.org/10.1021/acs.est.6b00823, 2016.

Gaston, C. J., Lopez-Hilfiker, F. D., Whybrew, L. E., Hadley, O., McNair, F., Gao, H., Jaffe, D. A., and Thornton, J. A.: Online molecular characterization of fine particulate matter in Port Angeles, WA: Evidence for a major impact from residential wood smoke, Atmos. Environ., 138, 99-107, https://doi.org/10.1016/j.atmosenv.2016.05.013, 2016.

Goldstein, A. H. and Galbally, I. E.: Known and unexplored organic constituents in the earth's atmosphere, Environ. Sci. Technol., 41, 1514-1521, 2007.

Hennigan, C. J., Sullivan, A. P., Collett, J. L., and Robinson, A. L.: Levoglucosan stability in biomass burning particles exposed to hydroxyl radicals, Geophys. Res. Lett., 37, L09806, https://doi.org/10.1029/2010GL043088, 2010.
Hennigan, C. J., Miracolo, M. A., Engelhart, G. J., May, A. A., Presto, A. A., Lee, T., Sullivan, A. P., McMeeking, G. R., Coe, H., Wold, C. E., Hao, W.-M., Gilman, J. B., Kuster, W. C., de Gouw, J., Schichtel, B. A., Collett, J. L., Kreidenweis, S. M., and Robinson, A. L.: Chemical and physical transformations of organic aerosol from the photo-oxidation of open biomass burning emissions in an environmental chamber, Atmos. Chem. Phys., 11, 7669-7686, https://doi.org/10.5194/acp11-7669-2011, 2011.

Hildebrandt, L., Donahue, N. M., and Pandis, S. N.: High formation of secondary organic aerosol from the photooxidation of toluene, Atmos. Chem. Phys., 9, 2973-2986, https://doi.org/10.5194/acp-9-2973-2009, 2009.

Hildemann, L. M., Markowski, G. R., Jones, M. C., and Cass, G. R.: Submicrometer Aerosol Mass Distributions of Emissions from Boilers, Fireplaces, Automobiles, Diesel Trucks, and Meat-Cooking Operations, Aerosol Sci. Technol., 14, 138-152, https://doi.org/10.1080/02786829108959478, 1991.

Iinuma, Y., Böge, O., Gräfe, R., and Herrmann, H.: MethylNitrocatechols: Atmospheric Tracer Compounds for Biomass Burning Secondary Organic Aerosols, Environ. Sci. Technol., 44, 8453-8459, https://doi.org/10.1021/es102938a, 2010.

Isaacman, G., Kreisberg, N. M., Worton, D. R., Hering, S. V., and Goldstein, A. H.: A versatile and reproducible automatic injection system for liquid standard introduction: application to in-situ calibration, Atmos. Meas. Tech., 4, 1937-1942, https://doi.org/10.5194/amt-4-1937-2011, 2011.

Isaacman, G., Kreisberg, N. M., Yee, L. D., Worton, D. R., Chan, A. W. H., Moss, J. A., Hering, S. V., and Goldstein, A. H.: Online derivatization for hourly measurements of gas- and particlephase semi-volatile oxygenated organic compounds by thermal desorption aerosol gas chromatography (SV-TAG), Atmos. Meas. Tech., 7, 4417-4429, https://doi.org/10.5194/amt-7-44172014, 2014.

Isaacman-VanWertz, G., Sueper, D. T., Aikin, K. C., Lerner, B. M., Gilman, J. B., de Gouw, J. A., Worsnop, D. R., and Goldstein, A. H.: Automated single-ion peak fitting as an efficient approach for analyzing complex chromatographic data, J. Chromatogr. A, 1529, Supplement C, 81-92, https://doi.org/10.1016/j.chroma.2017.11.005, 2017.

Jolleys, M. D., Coe, H., McFiggans, G., McMeeking, G. R., Lee, T., Kreidenweis, S. M., Collett, J. L., and Sullivan, A. P.: Organic aerosol emission ratios from the laboratory combustion of biomass fuels: BBOA emission ratios in chamber studies, J. Geophys. Res.-Atmos., 119, 12850-12871, https://doi.org/10.1002/2014JD021589, 2014.

Kahnt, A., Behrouzi, S., Vermeylen, R., Safi Shalamzari, M., Vercauteren, J., Roekens, E., Claeys, M., and Maenhaut, W.: One-year study of nitro-organic compounds and their relation to wood burning in $\mathrm{PM}_{10}$ aerosol from a rural site in Belgium, Atmos. Environ., 81, 561-568, https://doi.org/10.1016/j.atmosenv.2013.09.041, 2013.

Kanakidou, M., Seinfeld, J. H., Pandis, S. N., Barnes, I., Dentener, F. J., Facchini, M. C., Van Dingenen, R., Ervens, B., Nenes, A., Nielsen, C. J., Swietlicki, E., Putaud, J. P., Balkanski, Y., Fuzzi, S., Horth, J., Moortgat, G. K., Winterhalter, R., Myhre, C. E. L., Tsigaridis, K., Vignati, E., Stephanou, E. G., and Wilson, J.: Organic aerosol and global climate modelling: a review, Atmos. 
Chem. Phys., 5, 1053-1123, https://doi.org/10.5194/acp-5-10532005, 2005

Kelly, J. L., Michelangeli, D. V., Makar, P. A., Hastie, D. R., Mozurkewich, M., and Auld, J.: Aerosol speciation and mass prediction from toluene oxidation under high $\mathrm{NO}_{x}$ conditions, Atmos. Environ., 44, 361-369, https://doi.org/10.1016/j.atmosenv.2009.10.035, 2010.

Kessler, S. H., Smith, J. D., Che, D. L., Worsnop, D. R., Wilson, K. R., and Kroll, J. H.: Chemical Sinks of Organic Aerosol: Kinetics and Products of the Heterogeneous Oxidation of Erythritol and Levoglucosan, Environ. Sci. Technol., 44, 7005-7010, https://doi.org/10.1021/es101465m, 2010.

Kitanovski, Z., Grgić, I., Vermeylen, R., Claeys, M., and Maenhaut, W.: Liquid chromatography tandem mass spectrometry method for characterization of monoaromatic nitro-compounds in atmospheric particulate matter, J. Chromatogr. A, 1268, 35-43, https://doi.org/10.1016/j.chroma.2012.10.021, 2012.

Kitanovski, Z., Čusak, A., Grgić, I., and Claeys, M.: Chemical characterization of the main products formed through aqueous-phase photonitration of guaiacol, Atmos. Meas. Tech., 7, 2457-2470, https://doi.org/10.5194/amt-7-2457-2014, 2014.

Klein, F., Farren, N. J., Bozzetti, C., Daellenbach, K. R., Kilic, D., Kumar, N. K., Pieber, S. M., Slowik, J. G., Tuthill, R. N., Hamilton, J. F., Baltensperger, U., Prévôt, A. S. H., and El Haddad, I.: Indoor terpene emissions from cooking with herbs and pepper and their secondary organic aerosol production potential, Sci. Rep., 6, 36623, https://doi.org/10.1038/srep36623, 2016.

La, Y. S., Camredon, M., Ziemann, P. J., Valorso, R., Matsunaga, A., Lannuque, V., Lee-Taylor, J., Hodzic, A., Madronich, S., and Aumont, B.: Impact of chamber wall loss of gaseous organic compounds on secondary organic aerosol formation: explicit modeling of SOA formation from alkane and alkene oxidation, Atmos. Chem. Phys., 16, 1417-1431, https://doi.org/10.5194/acp16-1417-2016, 2016.

Lai, C., Liu, Y., Ma, J., Ma, Q., and He, H.: Degradation kinetics of levoglucosan initiated by hydroxyl radical under different environmental conditions, Atmos. Environ., 91, 32-39, https://doi.org/10.1016/j.atmosenv.2014.03.054, 2014.

Lambe, A. T., Miracolo, M. A., Hennigan, C. J., Robinson, A. L., and Donahue, N. M.: Effective Rate Constants and Uptake Coefficients for the Reactions of Organic Molecular Markers ( $n$ -Alkanes, Hopanes, and Steranes) in Motor Oil and Diesel Primary Organic Aerosols with Hydroxyl Radicals, Environ. Sci. Technol., 43, 8794-8800, https://doi.org/10.1021/es901745h, 2009

Lauraguais, A., Coeur-Tourneur, C., Cassez, A., and Seydi, A.: Rate constant and secondary organic aerosol yields for the gas-phase reaction of hydroxyl radicals with syringol (2,6-dimethoxyphenol), Atmos. Environ., 55, 43-48, https://doi.org/10.1016/j.atmosenv.2012.02.027, 2012.

Lauraguais, A., Coeur-Tourneur, C., Cassez, A., Deboudt, K., Fourmentin, M., and Choël, M.: Atmospheric reactivity of hydroxyl radicals with guaiacol (2-methoxyphenol), a biomass burning emitted compound: Secondary organic aerosol formation and gas-phase oxidation products, Atmos. Environ., 86, 155-163, https://doi.org/10.1016/j.atmosenv.2013.11.074, 2014.

Liu, C., Zhang, P., Wang, Y., Yang, B., and Shu, J.: Heterogeneous Reactions of Particulate Methoxyphenols with $\mathrm{NO}_{3}$ Radicals:
Kinetics, Products, and Mechanisms, Environ. Sci. Technol., 46, 13262-13269, https://doi.org/10.1021/es303889z, 2012.

Maenhaut, W., Vermeylen, R., Claeys, M., Vercauteren, J., and Roekens, E.: Sources of the $\mathrm{PM}_{10}$ aerosol in Flanders, Belgium, and re-assessment of the contribution from wood burning, Sci. Total Environ., 562, 550-560, https://doi.org/10.1016/j.scitotenv.2016.04.074, 2016.

May, A. A., Saleh, R., Hennigan, C. J., Donahue, N. M., and Robinson, A. L.: Volatility of Organic Molecular Markers Used for Source Apportionment Analysis: Measurements and Implications for Atmospheric Lifetime, Environ. Sci. Technol., 46, 12435-12444, https://doi.org/10.1021/es302276t, 2012.

Mohr, C., Lopez-Hilfiker, F. D., Zotter, P., Prévôt, A. S. H., Xu, L., Ng, N. L., Herndon, S. C., Williams, L. R., Franklin, J. P., Zahniser, M. S., Worsnop, D. R., Knighton, W. B., Aiken, A. C., Gorkowski, K. J., Dubey, M. K., Allan, J. D., and Thornton, J. A.: Contribution of Nitrated Phenols to Wood Burning Brown Carbon Light Absorption in Detling, United Kingdom during Winter Time, Environ. Sci. Technol., 47, 6316-6324, https://doi.org/10.1021/es400683v, 2013.

Net, S., Alvarez, E. G., Gligorovski, S., and Wortham, H.: Heterogeneous reactions of ozone with methoxyphenols, in presence and absence of light, Atmos. Environ., 45, 3007-3014, https://doi.org/10.1016/j.atmosenv.2011.03.026, 2011.

Ng, N. L., Canagaratna, M. R., Jimenez, J. L., Chhabra, P. S., Seinfeld, J. H., and Worsnop, D. R.: Changes in organic aerosol composition with aging inferred from aerosol mass spectra, Atmos. Chem. Phys., 11, 6465-6474, https://doi.org/10.5194/acp11-6465-2011, 2011.

Nolte, C. G., Schauer, J. J., Cass, G. R., and Simoneit, B. R. T.: Highly Polar Organic Compounds Present in Meat Smoke, Environ. Sci. Technol., 33, 3313-3316, https://doi.org/10.1021/es990122v, 1999.

Nolte, C. G., Schauer, J. J., Cass, G. R., and Simoneit, B. R.: Highly polar organic compounds present in wood smoke and in the ambient atmosphere, Environ. Sci. Technol., 35, 1912-1919, 2001.

Nussbaumer, T.: Verenum, Ingenieurbüro für Verfahrens-, Energieund Umwelttechnik, Hochschule Luzern and Schweiz (Eds.): Overview on Technologies for Biomass Combustion and Emission Levels of Particulate Matter, 11. Holzenergie-Symposium, 17 September 2010, ETH Zürich, TEMAS AG, Arbon., 2010.

Platt, S. M., El Haddad, I., Zardini, A. A., Clairotte, M., Astorga, C., Wolf, R., Slowik, J. G., Temime-Roussel, B., Marchand, N., Ježek, I., Drinovec, L., Močnik, G., Möhler, O., Richter, R., Barmet, P., Bianchi, F., Baltensperger, U., and Prévôt, A. S. H.: Secondary organic aerosol formation from gasoline vehicle emissions in a new mobile environmental reaction chamber, Atmospheric Chem. Phys., 13, 9141-9158, https://doi.org/10.5194/acp-13-9141-2013, 2013.

Rogge, W. F., Hildemann, L. M., Mazurek, M. A., Cass, G. R., and Simoneit, B. R. T.: Sources of fine organic aerosol 2. Noncatalyst and catalyst-equipped automobiles and heavyduty diesel trucks, Environ. Sci. Technol., 27, 636-651, https://doi.org/10.1021/es00041a007, 1993a.

Rogge, W. F., Hildemann, L. M., Mazurek, M. A., Cass, G. R., and Simoneit, B. R. T.: Sources of fine organic aerosol. 3. Road dust, tire debris, and organometallic brake lining dust: roads as sources and sinks, Environ. Sci. Technol., 27, 1892-1904, https://doi.org/10.1021/es00046a019, 1993b. 
Sandradewi, J., Prévôt, A. S. H., Weingartner, E., Schmidhauser, R., Gysel, M., and Baltensperger, U.: A study of wood burning and traffic aerosols in an Alpine valley using a multi-wavelength Aethalometer, Atmos. Environ., 42, 101-112, https://doi.org/10.1016/j.atmosenv.2007.09.034, 2008.

Schauer, J. J., Kleeman, M. J., Cass, G. R., and Simoneit, B. R. T.: Measurement of Emissions from Air Pollution Sources. 1. $\mathrm{C}_{1}$ through $\mathrm{C}_{29}$ Organic Compounds from Meat Charbroiling, Environ. Sci. Technol., 33, 1566-1577, https://doi.org/10.1021/es980076j, 1999.

Schauer, J. J., Kleeman, M. J., Cass, G. R., and Simoneit, B. R. T.: Measurement of Emissions from Air Pollution Sources. 3. $\mathrm{C}_{1}-\mathrm{C}_{29}$ Organic Compounds from Fireplace Combustion of Wood, Environ. Sci. Technol., 35, 1716-1728, https://doi.org/10.1021/es001331e, 2001.

Schauer, J. J., Kleeman, M. J., Cass, G. R., and Simoneit, B. R. T.: Measurement of Emissions from Air Pollution Sources. 5. $\mathrm{C}_{1}-\mathrm{C}_{32}$ Organic Compounds from GasolinePowered Motor Vehicles, Environ. Sci. Technol., 3, 1169-1180, https://doi.org/10.1021/es0108077, 2002.

Schmidl, C., Marr, I. L., Caseiro, A., Kotianová, P., Berner, A., Bauer, H., Kasper-Giebl, A., and Puxbaum, H.: Chemical characterisation of fine particle emissions from wood stove combustion of common woods growing in midEuropean Alpine regions, Atmos. Environ., 42, 126-141, https://doi.org/10.1016/j.atmosenv.2007.09.028, 2008a.

Schmidl, C., Bauer, H., Dattler, A., Hitzenberger, R., Weissenboeck, G., Marr, I. L., and Puxbaum, H.: Chemical characterisation of particle emissions from burning leaves, Atmos. Environ., 42, 9070-9079, https://doi.org/10.1016/j.atmosenv.2008.09.010, 2008b.

Simoneit, B. R., Rogge, W. F., Mazurek, M. A., Standley, L. J., Hildemann, L. M., and Cass, G. R.: Lignin pyrolysis products, lignans, and resin acids as specific tracers of plant classes in emissions from biomass combustion, Environ. Sci. Technol., 27, 2533-2541, 1993.

Trump, E. R., Epstein, S. A., Riipinen, I., and Donahue, N. M.: Wall effects in smog chamber experiments: A model study, Aerosol Sci. Technol., 50, 1180-1200, https://doi.org/10.1080/02786826.2016.1232858, 2016.

Waked, A., Favez, O., Alleman, L. Y., Piot, C., Petit, J.-E., Delaunay, T., Verlinden, E., Golly, B., Besombes, J.-L., Jaffrezo, J.L., and Leoz-Garziandia, E.: Source apportionment of $\mathrm{PM}_{10}$ in a north-western Europe regional urban background site (Lens, France) using positive matrix factorization and including primary biogenic emissions, Atmos. Chem. Phys., 14, 3325-3346, https://doi.org/10.5194/acp-14-3325-2014, 2014.
Weitkamp, E. A., Sage, A. M., Pierce, J. R., Donahue, N. M., and Robinson, A. L.: Organic Aerosol Formation from Photochemical Oxidation of Diesel Exhaust in a Smog Chamber, Environ. Sci. Technol., 41, 6969-6975, https://doi.org/10.1021/es070193r, 2007.

Williams, B. J., Goldstein, A. H., Kreisberg, N. M., and Hering, S. V.: An In-Situ Instrument for Speciated Organic Composition of Atmospheric Aerosols: Thermal Desorption Aerosol GC/MS-FID (TAG), Aerosol Sci. Technol., 40, 627638, https://doi.org/10.1080/02786820600754631, 2006.

Williams, B. J., Jayne, J. T., Lambe, A. T., Hohaus, T., Kimmel, J. R., Sueper, D., Brooks, W., Williams, L. R., Trimborn, A. M., Martinez, R. E., Hayes, P. L., Jimenez, J. L., Kreisberg, N. M., Hering, S. V., Worton, D. R., Goldstein, A. H., and Worsnop, D. R.: The First Combined Thermal Desorption Aerosol Gas Chromatograph - Aerosol Mass Spectrometer (TAG-AMS), Aerosol Sci. Technol., 48, 358-370, https://doi.org/10.1080/02786826.2013.875114, 2014.

Wong, Z., Chen, K., and Li, J.: Formation of vanillin and syringaldehyde in an oxygen delignification process, BioResources, 5, 1509-1516, 2010.

Yang, X.-Y., Igarashi, K., Tang, N., Lin, J.-M., Wang, W., Kameda, T., Toriba, A., and Hayakawa, K.: Indirect- and direct-acting mutagenicity of diesel, coal and wood burningderived particulates and contribution of polycyclic aromatic hydrocarbons and nitropolycyclic aromatic hydrocarbons, Mutat. Res. Toxicol. Environ. Mutagen., 695, 29-34, https://doi.org/10.1016/j.mrgentox.2009.10.010, 2010.

Ye, P., Ding, X., Hakala, J., Hofbauer, V., Robinson, E. S., and Donahue, N. M.: Vapor wall loss of semi-volatile organic compounds in a Teflon chamber, Aerosol Sci. Technol., 50, 822-834, https://doi.org/10.1080/02786826.2016.1195905, 2016.

Yee, L. D., Kautzman, K. E., Loza, C. L., Schilling, K. A., Coggon, M. M., Chhabra, P. S., Chan, M. N., Chan, A. W. H., Hersey, S. P., Crounse, J. D., Wennberg, P. O., Flagan, R. C., and Seinfeld, J. H.: Secondary organic aerosol formation from biomass burning intermediates: phenol and methoxyphenols, Atmos. Chem. Phys., 13, 8019-8043, https://doi.org/10.5194/acp13-8019-2013, 2013.

Yu, H.: Environmental carcinogenic polycyclic aromatic hydrocarbons: photochemistry and phototoxicity, J. Environ. Sci. Health Part C Environ. Carcinog. Ecotoxicol. Rev., 20, https://doi.org/10.1081/GNC-120016203, 2002.

Zhang, X., Schwantes, R. H., McVay, R. C., Lignell, H., Coggon, M. M., Flagan, R. C., and Seinfeld, J. H.: Vapor wall deposition in Teflon chambers, Atmos. Chem. Phys., 15, 4197-4214, https://doi.org/10.5194/acp-15-4197-2015, 2015. 